\title{
İlk Okuma Kitaplarında Değerler Eğitimi: Kültürel Miras Söylemi Etrafında Bir Analiz
}

\section{Dr. Öğr. Üyesi Cemil OSMANOĞLU*}

Atıf / @)- Osmanoğlu, C. (2018). İlk Okuma Kitaplarında Değerler Eğitimi: Kültürel Miras Söylemi Etrafında Bir Analiz, Çukurova Üniversitesi Illahiyat Fakültesi Dergisi, 18 (2), 1070-1101.

Öz- Değerler eğitimi son yıllarda ülkemizde ilgi görmektedir. Özellikle örgün eğitim sisteminde değerler eğitimi, daha fazla dikkat çekmektedir. Bu amaçla öğretim programlarında birçok değerin öğretiminden farklı şekillerde söz edildiği görülmektedir.

Türkçe öğretim programları, ders kitapları ile bu amaçla kaleme alınmış edebi eserlerin değerler eğitimi noktasında önemli olduğu bilinmektedir. Özellikle ilkokula yeni başlayan çocuklar, okudukları edebi eserlerle bir taraftan okuduğunu anlama kapasitelerini geliştirmekte, bir taraftan da değer yönelimlerini şekillendirmektedirler. Dolayısıyla ilk okuma sürecinde kullanılan metinlerin anlatım özelliklerinin yanı sıra değer iletimi bakımından da yeterli olması gerekmektedir.

Yukarıdaki kaygıdan hareketle bu çalışmada, ilkokul birinci sınıflara yönelik öğrencilerin okuma ve anlama yeterliklerini geliştirmeye çalışan eserlerde yer alan kültürel miras değerli ile bunu yansıtan belli şehirler tasvirleri incelenmeye çalışılmıştır. Amaçlı örneklem tekniğiyle çalışmada sadece belli illeri konu edinen eserlerin sunumuna odaklanılmış, ilçe, kasaba, belde gibi dar alanları konu edinen eserler dışarıda bırakılmıştır. Bu kapsamda örnek olarak üç gezi kitabı seçilmiş (Mehmet'in Gezi Anıları; Ankara'da, İstanbul'da, Çanakkale'de) ve nitel veri analizi ile kapak tasarımı, öne çıkarılan mekânlar, mekânların yazılı ve görsel tasviri, etkinlik örnekleri vb. başlıklar altında incelenmiştir. Inceleme sonucunda eserlerdeki kültürel miras öğelerinin görselleştirilmesinde kullanılan öğelerin etkili olduğu görülmüştür. Buna karşılık sözü edilen kültürel mirasla irtibatlı değerlerin yazılı tasvirinde çeşitli problemlerin olduğuna

\footnotetext{
* Erciyes Üniversitesi İlahiyat Fakültesi Din Eğitimi Anabilim Dalı e-posta: osmanoglu@erciyes.edu.tr
} 
değinilmiş, bu problemler çocukluk dönemi değer yönelimleri ile değerler eğitimi ve bunların kültürel mirasla ilişkisi çerçevesinde tartışılmıştır. İlkokul öğrencilerinin içinde bulunduğu gelişim aşaması dikkate alındığında, tarihsel ve kültürel mirasın sunumundaki problemlerin çocukların değer yönelimlerinde, kişilik oluşumlarında çeşitli sorunlara yol açabileceğinin altı çizilmiştir.

Anahtar sözcükler- Illk okuma kitabı, değer eğitimi, kültürel miras.

\section{$\S \S \S$}

\section{Giriş}

Değerler bireyin hayatına anlam katan önemli birer pusuladır. Neyi giyeceğimizden neye inanacağımıza, neyi beğenip neden uzak duracağımıza varıncaya kadar pek çok şey merkeze alınan değerler ekseninde şekillenir. Bundan dolayı değerler, gelenek içerisinde çeşitli ortam ve süreçlerde oluşan beşeri etkileşim ağlarında yeniden üretilir ve kültürel öğelerle örgütlenip nesilden nesle aktarılır, böylece geleceği şekillendirmeye devam eder. Kültür içerisinde enformel yollarla geleceğe nakledilen değerler, sistemli eğitim süreçlerine de konu edilerek yapılandıııır ve bilhassa eğitim programlarının ayrılmaz bir parçası haline gelir.

Örgün eğitim içerisinde değerler eğitimi son yıllarda gittikçe önem kazanmıştır. Türkiye'de ve dünyada değerler ve değerler eğitimi resmi ve özel okullarda, okul öncesinden yükseköğretime varıncaya kadar eğitimin hemen her kademesinde artan bir ilgiyle karşılanmaktadır. Nitekim son dönemlerde, son çocukluk ve ergenlik dönemlerinde gittikçe artan zararlı alışkanlıklar, madde bağımlıı̆ıı, şiddet ve suç oranları toplumun farklı kesimlerinde gittikçe artan belirsizliklere ve endişelere yol açmaktadır. Kültürel yabancılaşma, değer erozyonu ve ahlaki yozlaşma karşısında artan duyarlıkların bir neticesi olarak eğitim sistemlerinde değerlere ve değerler eğitimine daha fazla yer verildiği görülmektedir (Altıntaş, 2016).

Değerler ülkemizde bilhassa sosyal bilgilerle ilgili birçok öğrenme alanı, ünite ve konuyla ilişkilendirilmiştir. Bu anlamda Din Kültürü ve Ahlak Bilgisi, Hayat Bilgisi, Türkçe, Sosyal Bilgiler vb. derslerin öğretim programlarında açık ve örtük biçimde öğretime konu edilen birçok değer bulunmaktadır. Araştırmamızla yakından ilişkili olan Türkçe öğretim programlarının amaçlarına bakııdığında ise milli, manevi, ahlaki değerlere dikkat çekildiği, değerleri eğitimin önemli birer kazanımı olarak ele aldığı görülmektedir (Kaymakcan ve 
Meydan, 2015). Millî ve manevi değerleri özümsemiş, sağlıklı ve nitelikli bireylerden oluşan güçlü bir toplum oluşturma kaygısının Türkçe öğretim programlarında giderek daha da belirginleştiği, bilhassa 2005 yılından itibaren güncellenen öğretim programlarında bu kaygının "değer eğitimi" etrafında yapılan düzenlemelerle kendini gösterdiği anlaşılmaktadır (MEB, 2016). En son 2018 yılında güncellenen Türkçe Öğretim Programında "eğitim sistemimizin temel amacı değerlerimiz ve yetkinliklerle bütünleşmiş bilgi, beceri ve davranışlara sahip bireyler yetiştirmektir" dendiği görülmektedir. Söz konusu programın Türkçe dersi için ön gördüğü özel amaçlardan birisi de öğrencilerin "millî, manevi, ahlaki, tarihî, kültürel, sosyal değerlere önem vermelerinin sağlanması, millî duygu ve düşüncelerinin güçlendirilmesi”dir (MEB, 2018).

Türkçe Dersi Öğretim Programı'nın uygulanması sürecinde her sınıf düzeyinde 8 tema işlenmesi öngörülmüş, bu temalardan; "Erdemler", "Millî Kültürümüz", "Millî Mücadele ve Atatürk" temalarının her sınıf düzeyinde işlenmesinin zorunlu olduğu belirtilmiştir. Programda her sınıf düzeyinde zorunlu olduğu belirtilen ilgili temaların açılımı şöyle yapılmıştır: "Erdemler: Ahlak, alçak gönüllülük, azim, cömertlik, dayanışma, dostluk, dürüstlük, güven, iyilikseverlik, kardeşlik, merhamet, paylaşma, sabır, sadakat, saygı, sevgi, sılayırahim, vefa, vicdanlı olmak, yardımlaşma vb.; Milli Kültürümüz: Aile, bayrak, büyüklerimiz, dinî bayramlar, gelenekler, geleneksel sporlar, insan ilişkileri, kültürel miras, mekânlar, millî bayramlar, şehirlerimiz, sıla, tarihî mekânlar, tarihî şahsiyetler, tarihî eserlerimiz, Türkçe, vakıf kültürü, vatan, yurdumuz vb.; Millî Mücadele ve Atatürk: 15 Temmuz, Atatürk, Çanakkale, cesaret, Cumhuriyet, fedakârılı, gazilik, İstiklâl Marşı, kahramanlık, Kut'ül Amare, millî egemenlik, millî irade, millî kimlik, millî mücadele, Sarıkamış Harekâtı, şehitlik, vatanseverlik vb." (MEB, 2018). Söz konusu programda ders kitaplarına alınacak okuma metinlerinin de bu değerlere duyarlı olması gerektiği vurgulanmıştır.

Milli kültürün kazandırılmasında, Türkçe öğretim programında da değinildiği gibi, "kültürel miras" ve "şehirlerimiz" önemli iki öğedir. Somut ya da soyut bileşenleri ile kültürel miras, geçmişin izlerini taşıyan, sınanmış, tarihin süzgecinde elene elene günümüze taşınmış önemli değerler barındırmaktadır (Külcü, 2015). Bu değerler ise şehirlerle yakından ilgilidir (Kaynak ve Karabulut, 2016). Bir kültürlenme faaliyeti olan eğitim, hususen dil eğitimi, geçmişin mirasını şehirler üzerinden bu günün nesline aktararak geçmiş, bu gün ve gelecek arasında köprü kurabilir. Nitekim kültürel mirası öğretiminde şehirler ve şehirlerde mündemiç maddi ve manevi kültür varlıkları üzerinden yapılan sunumlara sıklıkla rastlanmaktadır. Belli amaçlarla inşa edilmiş mekânlardan 
oluşan şehirler taşıdıkları tarihsel ve güncel değerlerle bu değerlerin şekillendirdiği bir hafıza ya da kolektif bir bilinç sunarlar (Demirci, 2003). Bu bilinç sayesinde öğrenciler geçmişi doğru anlayarak bu günü daha iyi yorumlayabilir, kendilerinin ne olduğunu daha iyi kavrayabilir ve geleceğe ilişkin daha gerçekçi projeksiyonlar geliştirebilir (Dönmez ve Yeşilbursa, 2014). Elbette burada neyin, hangi amaçlarla ve nasıl bir anlayışla öğretime konu edileceği önemlidir (Selçuk, 1999).

Bilindiği gibi Türkçe öğretimi kapsamında, okuma ve yazmaya yeni başlayan çocukların okuduğunu anlama becerilerini geliştirmek amacıyla çeşitli kitaplar hazırlanmaktadır. Öğretmenler yer yer öğrencilerin okuma ve okuduğunu anlama becerilerini geliştirmek amacıyla söz konusu kitapları öğrencilere tavsiye edebilmektedirler. Bu tür kitapların öğrencilerin okuduğunu anlama ve anlamlandırma düzeyine hizmet etmesi yanında değer algısını şekillendirdiği, dolayısıyla değerler eğitiminde önemli bir yere sahip olduğu bilinmektedir (Sever, 2007). Nitekim çocuk kitapları çizginin ve dilin anlatım olanaklarıyla değişik karakter özelliklerini dolayısıyla çeşitli kişilikleri canlandırır. Karakterlerden ve onların ilişkilerinden esinlenerek meydana getirilen kurgularla çocukların insanı, doğayı ve yaşamı tanımasına ilişkin bir deneyim alanı oluşturulur (Özdemir, 2015).

İlk çocukluk dönemi ve bu dönemi içine alan temel eğitim, belli değerlerin özümsenmesi ve kimlik edinimi açısından son derece önemlidir. Bu dönem özdeşleşme ve taklit olgusunun çok güçlü olduğu bir dönemdir. Bu bakımdan çocukların okuyacağı metinler, içerdikleri değerler ile bunların aktarımı noktasında milli ve evrensel olan arasında dengeli, bireysel ve toplumsal gerçekliklerle uyumlu, tarihsel ve güncel olanla bütünleşmiş olmalıdır. Örgün eğitim kapsamında öğrenciye tavsiye edilen metinler Milli Eğitim Bakanlığının Türkçe Öğretim Programında öngördüğü gibi çocukların "Millî, manevi ve ahlaki değerlere önem vermeleri ve bu değerlerle ilgili duygu ve düşüncelerini güçlendirme" amacıyla da örtüşmelidir. Dolayısıyla bu süreçte kullanılan metinlerin dil ve anlatım özelliklerinin yanı sıra değer iletimi bakımından da yeterli olması gerekmektedir (Kardaş ve Cemal, 2017).

Temel eğitimin ilk kademelerinde okuma ve anlamayı ilerletmek, yazılı metinlere vukufiyet becerisini geliştirmek maksadıyla hazırlanan ve öğretmenlerce de zaman zaman seçilen ve öğrencilere tavsiye edilen kitapların hangi değerleri nasıl sunduğu araştırılması gereken bir konudur. Bu çalışmada yukarıdaki kaygılardan hareketle ilkokul birinci sınıflara yönelik öğrencilerin okuma ve anlama yeterliklerini geliştirmeye çalışan eserlerde yer alan "kültürel miras" söylemi ve bu çerçevede belli şehirlerin sunumu incelenmeye 
çalışılacaktır. Bu amaçla çalışmada bakanlığın da öngördüğü "Milli Kültürümüz" teması içerisinde yer alan "şehirlerimiz" değeri ekseninde belirli şehir sunumlarına odaklanılacaktır. Kültürel miras ve onun şehir tasavvurun farklı parametreler ile ilişkisinin eğitsel yansımalarına odaklanmak, temel eğitim çağı çocuklarının değer yönelimlerinin, özellikle kimlik olgusunun eğitim sistemiyle nasıl şekillendirildiği noktasında önemli ipuçları sunabilir. Bu bakımdan bu araştırmanın temel problemini "Illk okuma kitaplarında nasıl bir kültürel miras sunumu yapılmaktadır? Bu sunum nasıl bir şehir tasavvuru ile ortaya konmaktadır? Söz konusu tasavvurun çocukların değer yönelimi ve kimlik oluşumuna muhtemel imaları neler olabilir?" soruları oluşturmaktadır.

\section{Yöntem}

\subsection{Eserlerin seçimi}

Türkiye'de ilkokullarda okuma ve okuduğunu anlama çalışmalarına yönelik hazırlanan birçok kitap ve kitap seti bulunmaktadır. Bilhassa bir bütün halinde kaleme alınan setler önemli ölçüde okuma kitaplarıyla bunlara yönelik anlama, kavrama çalışmalarını içeren çalışma yapraklarından oluşmaktadır. Araştırmaya konu edilen çalışma Sevgi Şahin tarafından hazırlanan, Elif İkiztepe tarafından görselleştirilen Mehmet'in Gezi Anıları (Limon Kitap, İstanbul) isimli settir. Set her biri belli şehirlere yapılan gezileri konu edinen toplam 10 kitaptan oluşmaktadır. Her biri 16 sayfadan oluşan kitapların isimleri şöyledir: Abant'ta, Ankara'da, Ayvalık'ta, Çanakkale'de, Foça'da, İstanbul'da, Kapadokya'da, Olimpos'ta, Selçuk'ta, Uludağ'da. Set, yukarıda isimleri zikredilen kitaplarda yer verilen bilgileri yoklayan belli etkinliklerin yer aldığı bir de çalışma ekiyle desteklenmiştir. Burada her bir kitapta yer alan belli kazanımları ölçmeye dönük çeşitli açık uçlu, çoktan seçmeli soruların yanında bulmaca gibi etkinlikler de yer almaktadır.

$\mathrm{Bu}$ çalışmada yukarıda işaret edilen kitaplardan yalnızca Ankara'da, Çanakkale'de ve İstanbul'da başlıklı kitaplar ile bunlara yönelik etkinlikleri içeren çalışma sayfaları incelemeye konu edilmiştir. Araştırma sorularının çok boyutlu karakteri örneklemi daraltmayı gerektirmiştir. Nitekim nitel araştırmalarda geniş bir örneklemden ziyade dar bir alana odaklanmak daha gerçekçi ve derinlikli bir anlama ve açıklama imkânı sunabilmektedir. Yalnızca Ankara'da, Çanakkale'de ve İstanbul'da isimli kitapların seçilme sebebi ise sadece bu eserlerin belli illeri bir bütün olarak incelemeye konu etmeleridir. Incelenen sette sadece bu kitaplar belli bir ilin nasıl bir tabloyla okuyucuya sunulduğunu anlamamıza imkân sunacak kapsamdadır. Çalışmada şehir 
tasavvurunu iller üzerinden okumanın daha bütüncül bir kavrayış sunabileceği varsayılmıştır.

\subsection{Bulguların elde edilmesi ve yorumlanması}

Araştırma tarama modeline dayalı olarak yürütülmüştür. Tarama modelinde geçmişte ya da halen var olan bir durum var olduğu şekliyle betimlenmeye çalışılır. Araştırmaya konu olan olay, birey ya da nesne kendi koşulları içinde olduğu gibi tanımlanmaya çalışılır (Karasar, 2000: 77). Araştırma verilerinin elde edilmesinde doküman incelemesi yöntemi kullanılmıştır. Doküman incelemesi yöntemi basılı materyalin farklı amaçlarla incelenmesi için diğer veri toplama yöntemleriyle birlikte kullanılabildiği gibi tek başına da kullanılabilmektedir. Nitel araştırmalarda doküman incelmesi ya da analizi, araştırılması amaçlanan olgu veya olgular hakkında bilgi içeren yazılı materyallerin analizini kapsar (Yıldırım ve Şimşek, 2005: 187). Araştırma materyalinin analizi sürecinde veriler öncelikle yoğun şekilde betimlenmiştir. Nitekim betimsel analiz nitel araştırmalarda sıklıkla kullanılan bir teknik olup elde edilen verilerin araştırmanın ana ve alt problemleri ışığında önceden belirlenen temalara göre özetlenip yorumlanmasına dayanır (Yıldırım ve Şimşek, 2005: 224). Bu araştırmada ele alınan metinler öncelikle sırasıyla kapak tasarımı, öne çıkarılan mekânlar, mekânlara ayrılan yer, mekânların yazılı tasviri, mekânların görsel tasviri, etkinlik örnekleri başlıkları altında betimlenmeye çalışılmıştır. İlgili başlıklar altında ayrıntılarıyla betimlenen muhteva, ardından araştırmanın problemi bağlamında eleştirel söylem analizine tabi tutulmuştur. Bu bağlamda şehir sunumunun yazılı ve görsel öğeler üzerinden nasıl kurgulandığı, şehirlerin tasvirinin kültürel miras aktarımı ekseninde nasıl konumlandırıldığı incelenmeye çalışılmıştır.

\section{Bulgular ve yorumu}

\section{1. Kapak tasarımı}

Bir eserin kapağı, tıpkı bir insanın siması ve dış görünüşü gibidir. Bir insanla karşılaştığımızda ilk önce kılık kıyafetine ve simasına bakarak bir fikir edinmeye böylelikle ona bir anlam yüklemeye çalışırız. Kitapların ön ve arka yüzleri de okura kitap hakkında derli toplu bir fikir vermesi açısından temsil kabiliyeti yüksek unsurlardır. Kitaplarda özellikle ön kapağın görsel açıdan dikkat çekici olmasının yanında içeriğin bütünü hakkında anlamlı ve doğru bir fikir vermesi de gerekmektedir. İncelenen eserlerin kapak resimleri aşağıda topluca verilmiştir. 
Kitap kapaklarına ilişkin görseller
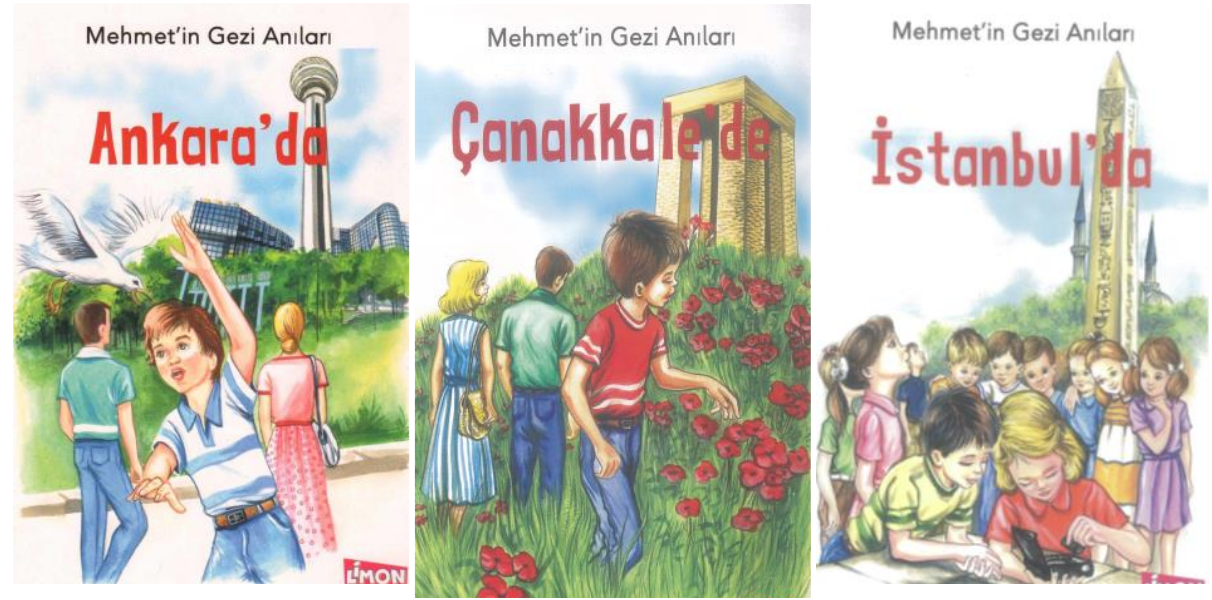

Kitap kapaklarına bakıldığında Ankara'nın, önünde yer alan yeşil alanıyla Atakule ve bitişiğindeki modern mimari öğelerle, Çanakkale'nin yeşil, çiçekli bir görselin ardına yerleştirilen Şehitler Anıtıyla, İstanbul'un ise önde Dikilitaş ve ardında kubbesi yeterince belirgin olmayan, iki küçük minaresi görünen bir camiyle temsil edilmeye çalışıldığı anlaşılmaktadır. Ankara ve Çanakkale'de Mehmet anne babasıyla, İstanbul'da ise bu sefer arkadaşlarıyla birlikte görülmektedir. Mehmet Ankara'da Atakule'nin önünde beyaz güvercin uçurmakta, Çanakkale'de Şehitler Abidesi önünde kırmızı renkli çiçekler arasında onlara dokunarak gezinmekte, İstanbul'da ise elindeki fotoğraf makinesiyle uğraşan bir arkadaşıyla birlikte görünmekte, arka planda ise kendine yakın yaş ve fiziksel özelliklerde olduğunu söyleyebileceğimiz çocuklar durmaktadır.

Bilindiği gibi Ankara Türkiye tarihinde Cumhuriyet sonrası süreçte demokrasi, parlamento fikirlerine hayatiyet kazandırması, modern devlet aygıtının bütün temel kurucu organizasyonlarını barındırmasıyla öne çıkmıştır. Türkiye tarihinde cumhuriyet ve demokrasi olgularının temellerinin büyük ölçüde burada şekillenmesi, bu sürecin mimarı olan Atatürk'ün siyasal faaliyetlerini önemli ölçüde buradan yürütmesi, dahası onun kabrinin burada olması söz konusu şehre farklı bir anlam ve hüviyet kazandırmıştır. Burada beyaz güvercin temasının kapağa söz konusu arka planla birlikte taşınması suretiyle, okura Ankara'da inşa edilen yeni devlet ve yönetim anlayışı ile onu kuran iradenin bir özgürlük ve barış hareketi şeklinde anlaşılması gerektiği mesajı verdiği söylenebilir. Atakule'nin ön cepheden, arkaya doğru hafif esnetilerek sunulmuş görseli ise bu söylemi iddia, güç ve heybet bakımından 
güçlendirmeye çalışmaktadır. Ankara'nın Cumhuriyet dönemi öncesine ait (örneğin Bizans, Osmanlı vb.) yapılarını anımsatan herhangi bir öğenin kapağa yansıtılmadığı görülmektedir.

Çanakkale, yakın tarihimizde Osmanlı topraklarını işgal etmeye çalışan güçlere karşı topyekûn verilen mücadelenin simgesi olmuş bir ilimizdir. Çanakkale ayrıca binlerce yıllık bir geçmişin hafızasını yansıtan antik Truva kalıntılarını da barındırmaktadır. Çanakkale'de isimli kitabın kapağının önemli bir bölümü kırmızı gelinciklerle süslenmiştir. Kitabın ana karakteri olan Mehmet kapakta gelinciklere eliyle dokunmakta, onları sevmektedir. Gelincik, genelde ilkbahar ve yaz aylarında açan, $30 \mathrm{~cm}$.ye kadar uzanan gövdesi ve birkaç kırmızı yapraktan oluşan çiçek dokusuyla en hafif bir rüzgârda bile hareket eden oldukça narin bir bitkidir. Birçok özelliğinden dolayı insanlarla özdeşleştirilen bu bitkinin çiçeği hüzün, aşk, kavuşamama gibi anlamlar taşımaktadır. Ayrıca onun ince olan yaprakları ve kolayca hareket edip eğilebilen ince uzun gövdesi nezaketi, narinliği insan yüreğinin hassasiyetini temsil etmektedir. Hafif bir rüzgârda bile koparak yok olabilen çiçek dokusu ise insanın narinlik ve kırılganlığının remzi anlamına gelmektedir. Topraktan kopartıldığı anda solup kurumaya yüz tutması ise insanın yüreğindeki sevginin özenle saklanması ve korunması ile ilişkilendirilmiştir. Kitap kapağında gelinciklerin kullanılarak Çanakkale'nin temsil ettiği değerlerin hassasiyetine dikkat çekilmiş, bu değerlerin özenle korunması gerektiğine işaret edilmiş olabilir. Gelinciklerden oluşan bir zemin üzerine yerleştirilen Çanakkale Şehitler Abidesi ise bu nezaket ve hassasiyete güç ve heybet katarak söz konusu değerleri adeta abideleştirmekte ve canlı bir yapıya kavuşturmaktadır.

İstanbul, tarihi oldukça eskilere uzanan, geçmişten bu yana birçok uygarlık ve devletin izlerini taşıyan kadim bir kenttir. İstanbul Osmanlılarca fethedildikten sonra adeta bir İslam şehrine dönüşmüş, bilhassa Süleymaniye, Sultanahmet, Eyüp, Süleymaniye gibi yapılar şehre farklı bir anlam kazandırmıştır. Şehir, halen, Roma ve Bizans elinde şekillendiği dönemlerden kalma birçok eseri de barındırmaktadır. Ayasofya bunların başında gelmektedir. Ayrıca İstanbul boğazı ve boğaz köprüleri, erguvan çiçeği, Topkapı Sarayı gibi birçok farklı öğeyle de görselleştirilmek suretiyle temsilde kullanılabilmektedir. Son yıllarda giderek artan oranda turist çekmekte olan kentin adeta bir turizm bölgesine dönüştüğü söylenebilir. Çalışmada incelenen İstanbul'da isimli eserin kapağı kabaca bir gurup çocuk ile arkalarında yer alan Dikilitaştan oluşmaktadır. Kapakta ayrıca Dikilitaş'ın arkasına iki minare yerleştirilmiştir. Sultanahmet meydanını merkeze aldığı anlaşılan kapak tasarımının İstanbul'un hem Osmanlı öncesi hem de Osmanlı sonrası 
panoramasına ilişkin temaları birlikte içerme kaygısı taşıdığı, ayrıca bölgenin turistik kapasitesi de düşünüldüğünde turizm eksenli hassasiyetleri öne çıkardığı anlaşılmaktadır. Dikilitaş yerli ve yabancı turistlerin sıklıkla ziyaret ettikleri, İstanbul'un tarihsel olarak en eski eserlerinden biridir. Kapakta yer verilen öğelerden Dikilitaş'ın daha vurgulu ve dikkat çekici bir tonla en öne, cami kubbe ve minare resimlerinin en arkaya çok daha küçük biçimlerle resmedilmesi tarihsel ya da turistik hassasiyetlerin öne çıkarılması şeklinde okunabilir. En önde Ahmet'in fotoğraf makinesiyle ilgilendiğini gösteren tema ise bu turizm ve tarih vurgularını tamamlar niteliktedir.

\section{2. Öne çıkarılan mekânlar}

Edebi eserlerde, özellikle seyahat ve gezi çalışmalarında gezinti ya da ziyaret amacıyla seçilen, öne çıkarılan, gezilmesi tavsiye edilen mekânlar önemlidir. Söz konusu olan şehir olduğunda bu tavır ilgili şehrin hangi mekânlar üzerinden sunulduğuna, okunduğuna ve anlaşıldığına ilişkin önemli ipuçları sunabilir. Şehirlerin belli mekânlarla ilişkilendirilerek çocuğa aktarılması, çocuğun söz konusu mekânların temsil ettiği kişi, kurum, olay, değer, düşünce vb. ile ayniyet kurarak kendi kimliğini inşa etmesi sürecinde önemli bir yapısal öğe halini alabilmektedir.

Ankara'da Mehmet'in ailesiyle birlikte gerek ziyaret etmek gerekse konaklamak amacıyla gittiği mekânlar sırasıyla şunlardır: Atatürk Orman Çiftliği, Neva Palas, Aslanlı Yol, Anıtkabir, Barış ve Zafer Kuleleri (İsmet İnönü'nün kabri), Ulus Meydanı (Atatürk heykeli), Birinci Meclis (Kurtuluş Savaşı Müzesi), İkinci Meclis, Güven Park, Güven Anıtı (Kızılay), Resim Heykel Müzesi, Gençlik Parkı. Görüldüğü gibi Ankara gezisinde tercih edilen mekânlar Cumhuriyet sonrası döneme ait mekânlardır. Bu mekânların en önemli özelliği yeni kurulan Cumhuriyet'in kurucu felsefesinin yanında, onun varlığa, insana ve mekâna bakışıyla şekillenmiş olmalarıdır. Yazar Ankara'nın tarihi simgelerinden olan Hacı Bayram Camii ya da Cumhuriyet sonrasında yapılan Kocatepe Camii gibi önemli dini mekânları gezilecek yerler arasına almamıştır. Dahası bu şehrin tarihsel güncel mimarisini yansıtan başka bölgeleri ve mekânları da bulunmaktadır. Elbette hangi mekânların öne çıkarılacağı bir tercih meselesidir. Fakat burada öne çıkarılan mekânlarla öğrencinin Ankara'yı tarihi ve bu günüyle, maddi-manevi öğeleriyle bir bütün olarak tanıyıp tanıyamayacağı, gerektiği şekilde anlayıp anlayamayacağı merak konusudur.

Mehmet'in Çanakkale'de uğradığı duraklar ya da geçtiği mekânlar ise sırasıyla şöyledir: Antik Truva Kenti, Truva Atı, Feribotla Çanakkale Boğazı (Şehitler Abidesi, Dur Yolcu... görüntüleri eşliğinde), Çanakkale Şehitliği ve 
Şehitler Anıtı, Namık Kemal'in kabri (Bolayır). Görüldüğü gibi Çanakkale gezisinde ziyaret edilen mekânlar bir önceki eserdekilerden daha azdır. Bununla birlikte yazarın şehrin uzak ve yakın tarihine ilişkin belli bir panorama oluşturma gayreti dikkati çekmektedir. Oysa daha önce üzerinde durulmuş olan Ankara için böyle bir değerlendirme yapmak güçtür. Çanakkale bağlamında öne çıkarılan mekânların oldukça az olduğu görülmektedir. Bu durumun Çanakkale'nin coğrafi özellikleri ile ilgili olabilir. Zira coğrafi alan geniş olduğunda kısa bir gezide gezilecek yerlerin sayısı azalabilmektedir. Bununla beraber Çanakkale bölgesinde gerek tarihi gerekse turistik amaçlarla gezilebilecek, yazarın gönderme yaptığı mekânların dışında birçok mekân bulunmaktadır. Bunlar içerisinde cami, şehitlik, çarşı, kale, müze ve anıtlar vb. örnek verilebilir. Bunlara yer vermeyerek yazarın Çanakkale'yi Truva ve Gelibolu yarımadası ekseninde okumaya çalıştığı anlaşılmaktadır.

İstanbul gezisinde ise sırasıyla şu mekânlara uğranmıştır: Boğaz Köprüsü (İstanbul Boğazının seyri), Gülhane Parkı, Topkapı Sarayı ve Hazine Dairesi, Arkeoloji Müzesi, Çocuk Müzesi, Yerebatan Sarnıcı, Ayasofya Müzesi, Sultanahmet Camii, Alman Çeşmesi, Dikilitaş, Sahaflar Çarşısı (Beyazıt Meydanı), Matbaa Müzesi. İstanbul'da isimli kitapta da yazarın tarihsel olarak belli bir kronolojik panorama oluşturma gayreti gösterdiği anlaşılmaktadır. Dikilitaş, Ayasofya, Yerebatan Sarnıcı gibi İslam öncesi İstanbul tarihinin izlerini taşıyan yapıların yanında Sultanahmet Camii, Topkapı Sarayı, Sahaflar Çarşısı gibi daha çok Osmanlı tarihiyle özdeşleşmiş mekânlar ve Boğaz Köprüsü, Arkeoloji Müzesi, Çocuk Müzesi gibi daha yakın dönem unsurları bu kapsamda birlikte ele alınmaya çalışılmıştır.

Mekân seçimi olarak Ankara'da neredeyse tamamen Cumhuriyet dönemine odaklanılmasına karşın Çanakkale ve İstanbul'da daha sentezci ya da bütüncül kaygıların öne çıktığı görülmektedir. Mekân seçimiyle kapak tasarımları arasında kısmen bir ötüşme olduğu söylenebilir. Bununla beraber şehirleri belli mekânlar üzerinden işleme noktasında Çanakkale'de ve İstanbul'da isimli kitaplar Ankara'da isimli kitaba göre daha bütüncül bir yapı arz etmektedir, denebilir. Bu durum en azından bu iki tema noktasında kültürel mirasın aktarımında daha bütüncül ve objektif bir tavır olarak değerlendirilebilir.

\subsection{Mekânlara ayrılan yer}

Bir şehri belli mekânları öne çıkararak sunarken belli mekânların tercih edilmesi yanında onlara ayrılan yer de önemlidir. Bunun için kelime sayısı önemli bir gösterge olarak alınabilir. 
Incelenen eserlerden ilki olan Ankara'da gezilen belli başı mekânlar ile onların anlatımında kullanılan kelime sayısı sırasıyla şöyledir: Atatürk Orman Çiftliği: 39; Anıtkabir: 98; İsmet İnönü Kabri: 45; Atatürk Heykeli (Ulus Meydanı): 19; Birinci Meclis: 44; İkinci Meclis: 26; Güven Park (Kızılay): 10; Resim Heykel Müzesi: 15; Gençlik Parkı: 21. Burada görüldüğü gibi Anıtkabir, İsmet Inönü Kabri ve Birinci Meclis ağırıklı bir sunum yapılmışıı. Ardından kelime sıklığı bakımından Atatürk Orman Çiftliği gibi mekânlar gelmektedir. Yazarın Ankara sunumunda öne çıkardığı mekânlar ve burada görüldüğü gibi onların anlatımında kullanılan kelime sayısı daha çok Cumhuriyet ve onun kurucu değerlerine, bilhassa da Atatürk'ün manevi şahsına odaklanan ve bu çerçevede oluşan mekân tasvirleriyle öne çıkmaktadır. Bu sunum tarzının öğretim programlarındaki "Atatürkçülük ve Milli Mücadele" temasıyla ilişkili olduğu söylenebilir. Bununla beraber Ankara sunumunda öne çıkarılan mekânların kültürel miras sunumu etrafında daha kuşatıcı ve bütünlüklü oluşturulması daha anlamlı olacaktır. Zira tarihsel duyarlıkları ve kronolojik kapsayıcııığ zayıf bu mekân tasavvurunun tarih ve kültürün tek yanlı anlaşılmasına, öğrencilerin şehirleri tanımak suretiyle edinecekleri değer yönelimlerinin eksik şekillenmesine yol açabilir.

Çanakkale'de gezilen belli başlı mekânlar ile onların anlatımında kullanılan kelime sayısı sırasıyla şöyledir: Truva Kenti: 227; Feribotla Çanakkale Boğazı (Şehitler Abidesi, "Dur Yolcu..." görüntüleri eşliğinde): 71; Çanakkale Şehitliği ve Şehitler Anıtı: 92; Namık Kemal'in Kabri: 26. Görüldüğü gibi kitapta Truva kentinden daha çok söz edilmiş, Çanakkale ve Şehitlik olgusunun sunumunda ise daha az kelime kullanılmıştır. Ancak 'vatan şairi' olarak bilinen Namık Kemal'in kabrinin ziyareti ile vatan eksenli sunumun nicel parametreler bağlamında dengelenmeye çalışıldığı düşünülebilir. Nitekim Çanakkale anlatımında vatan ve şehitlik önemli iki temadır. Bununla beraber "Çanakkale'de" isimli kitabın mekân olarak Truva ve Çanakkale olarak ikiye ayrılarak ele alınmasının esprisi yeterince anlaşılamamıştır. Zira kitabın hemen girişinde kurulan ilk cümlede şöyle denmiştir: "Mehmetlerin bugünkü durakları Çanakkale'ydi. Antik Truva Kentini gezeceklerdi." Truva anlatımının hemen ardından, yani kitabın yarısından daha fazla ilerledikten sonra gelen "Çanakkale'ye gitmek üzere feribota bindiler" ifadesi kafa karışıkığına yol açabilmektedir. Burada Çanakkale ile ilgili mekânsal tasvir tam anlamıyla tutarlı bir dengeye oturtulamamıştır. İster istemez akla şu sorular gelmektedir: Çanakkale ve Truva iki ayrı kent midir? Çanakkale Truva'dan sonra mı gelmektedir? Ayrıca kitapta Truva'dan daha fazla söz edilmesine rağmen 
kapakta Truva'yı anımsatan herhangi bir öğenin yer almaması da problem olarak not edilebilir.

Araştırmada incelenmeye çalışılan son eserin tasvir ettiği şehir olan İstanbul'da gezilen belli başlı mekânlar ile onların anlatımında kullanılan kelime sayısı sırasıyla şöyledir: Gülhane Parkı: 65; Topkapı Sarayı: 51; Arkeoloji Müzesi: 36; Çocuk Müzesi: 7; Yerebatan Sarnıcı: 12; Ayasofya Müzesi: 25; Sultanahmet Camii: 23; Alman Çeşmesi: 5; Dikilitaş: 34; Sahaflar Çarşısı (Beyazıt Meydanı): 22. Görüldüğü gibi kelime sayısı açısından bakıldığında İstanbul sunumunda tarihsel ve turistik mekânlara daha fazla yer ayrılmıştır. Ancak tarihsel kimliğinden çok bu gün doğal güzelliğiyle tanınan Gülhane Parkından neden en fazla sözcükle söz edildiği, buna karşın örneğin Ayasofya'nın bunun yarısından daha az sözcükle tanıtılığı anlaşılamamıştır. Her ne kadar Alman Çeşmesi gibi kimi unsurların metne ne amaçla yerleştirildiği yeterince anlaşılamamış olsa da Topkapı Sarayı hakkında etraflıca bilgi verilmesi İstanbul'un belli bir tarihsel süreklilik ekseninde bütüncül olarak algılanması bakımından anlamlı olabilir. Ayrıca bu içerik kitap kapağıyla da önemli ölçüde örtüşmektedir.

\subsection{Mekânların yazılı tasviri}

Bilindiği gibi okul öncesi ve ilkokul dönemleri çocukların dil gelişimi açısından son derece önemlidir. Yazılı anlatıma dayalı edebi ürünlerin yoğun biçimde kullanıldığı bu dönemlerde çocuklar edebi eserlerin içeriği üzerinden belli değerleri tanımakta, belli karakter, kahraman ya da kişileri kendilerine yakın bularak kişilik ve kimlik gelişimlerini yapılandırmaktadırlar. Bu bakımdan edebi eserlerin gramer ve dil bilgisi kuralları açısından nitelikli olmasının yanında anlatımının çocuğun gelişimsel özellikleriyle uyumlu, ideolojik saplantı ve ön yargılı yaklaşımlardan arınık, yazıldığı ülke ve hitap ettiği toplumun tarihsel ve güncel sosyokültürel gerçeklikleriyle tutarlı olması gerekmektedir.

Ankara'da isimli eser Mehmetlerin öğle üzeri beyaz renkte bir otomobille Atatürk Orman Çiftliği yakınlarından Ankara'ya girmeleriyle başlar. Bu esnada Mehmet'in babası uzakta bir çiftliği göstererek oranın Atatürk Orman Çiftliği olduğunu belirtir. Mehmet'in babası buranın zamanında bir bataklık olduğunu, Atatürk'ün burada bir çiftlik kurulmasını isteyince etrafındakilerin "burada ağaç yetişmez" demeleri üzerine Atatürk'ün gülümseyerek "bekleyin, görün” dediğini belirtir. Bu sırada gözleri parlayan Mehmet "Ata'mız da bizim gibi çevreciymiş" ifadelerini kullanır. Babası ise diyaloğu "evet evlat! Kesilen bir ağacın ardından ağlayacak kadar çevreciymiş" şeklinde tamamlar (s. 2-3). Görüldüğü gibi bu diyalogda "Ata'mı" kelimesiyle ortak bir değer olarak sunulan Atatürk'ün "bizim 
gibi" ve "çevreci" olduğu vurgulanmakta bu iddia Atatürk Orman Çiftliğinin kuruluşundaki bir tartışmayla desteklenmektedir.

$\mathrm{Bu}$ girişin hemen ardından Mehmet ve ailesi kalacakları otele gelirler. Otelin adı Neva Palas'tır. Eserde otel ile ilgili bir görselin dışında herhangi bir bilgi bulunmamaktadır. Otelin girişinde Mehmet annesine Anıtkabir'e ne zaman gideceklerini sorar. Annesi ise bu gün dinleneceklerini oraya yarın gidebileceklerini belirtir. Ertesi sabah "erkenden" başlanan Anıtkabir gezisi bağlamında Aslanlı Yol'da ilerlerken Mehmet duygularını şöyle dile getirir: "Çok heyecanlıyım", "görmeyi en çok istediğim yerdeyim." Bunun üzerine babası bahçedeki "gençleri" göstererek "heyecanlı olan yalnızca sen değilsin" der (s. 5). Görüldüğü gibi burada Anıtkabir, "erkenden" yola çıkılan, ilk görülmesi gereken, "en çok" görülmesi arzulanan, "gençlerin" ilgi gösterdiği, "çok heyecanlandıran" bir yerdir.

Anıtkabir'de aile, öncelikle Atatürk'ün mozolesinin bulunduğu salona girer. Mehmet burada "fısıltıyla" annesine mozolenin ne demek olduğunu sorar ve "büyük, gösterişli mezar" yanıtını alır. Ardından annesi Mehmet'i babasının yanına göndererek fotoğraflarını çeker. Daha sonra Anıtkabir'deki diğer bölümler gezilmeye başlanır. Atatürk'ün özel eşyalarının sergilendiği salona girince Mehmet'in annesi "Atatürk ne kadar zevkliymiş", "şu giysilerin güzelliğine bakın" der. Bu esnada aile Atatürk'e ait askeri bir üniformayı incelemektedir (s. 7).

Çalışmanın ilerleyen bölümlerinde "Ata'mızın" naaşını taşıyan top arabası ve ikinci "cumhurbaşkanımız" ve "Ata'mızın en yakın silah arkadaşı" olan İsmet İnönü'nün sembolik naaşı ziyaret edilir. Ardından Ulus Meydanı'ndaki Atatürk Heykeli'ne geçilir (s. 9). Heykel "çok güzel" bulunur, Mehmet "uzunca bir süre" gözlerini ondan ayıramaz ve babası da "bol bol" fotoğraf çeker. Ardından "eski" bir binanın önünde durulur (s. 10). Babası Mehmet'e bu binaya "iyi bakması” gerektiğini söyler. Ardından buranın ilk meclisin toplandığı yer olduğunu, Türkiye Cumhuriyeti'nin temellerinin burada atıldığını, bu gün ise Kurtuluş Savaşı Müzesi olarak kullanılmakta olduğunu ekler. Anlatımın devamında binanın içindeki "her şeyin" "olduğu gibi" korunduğu, ilk milletvekillerinin oturdukları sıraların hala durduğu vurgulanır. Ardından geçilen İkinci Meclis Binasında Mehmet'in babası "tarihi binaların" insanı etkilediğinin altını çizerek, en önemli kararların burada alındığı, Cumhuriyetin burada ilan edildiği, Mustafa Kemal'in burada cumhurbaşkanı seçildiği açıklamasını yapar. Devamında Kızılay’daki Güven Park'a gidilir, Güven Anıtı önünde durup anıt "seyredilir" (s. 13). 
Kitabın sonlarına doğru Resim Heykel Müzesine gidilir. Müze önündeki heykel "olağanüstü" bulunur, "hayranlıkla" izlenir ve yine "bol bol" fotoğraf çekilir. Ankara gezisinin son durağı "biraz eğlenmek" amacıyla gidilen Gençlik Parkı'dır. Burada dönme dolap ve çarpışan arabalara binilir ve "her şeyin" "çok güzel" olduğu değerlendirmesi ile kitabın ana metni bitirilir. Kitabın son sayfası olan günlük kısmında Mehmet, o gün olup bitenleri yazmakta, bir bakıma yaşadıklarını özetini yaparak değerlendirmektedir. Bu kısımda Mehmet Anıtkabir'i gezerken çok duygulandığını, Atatürk ile İsmet İnönü'nün yakın arkadaş olduklarını, en önemli kararları birlikte aldıklarını yazarak, kendi kendine "demek ki onlar kötü gün dostuymuş" değerlendirmesinde bulunarak Ankara'yı "çok sevdiğini" belirtir (s. 16).

Ankara anlatımı bağlamında kitapta oluşturulmaya çalışılan gerçeklik kitabın kapağı, seçilen mekânlar ile bunların sunumunda kullanılan kelime sayısıyla ile uyumludur. Yukarıda doğrudan alıntılarla verilen örneklerde kullanılan dile bakıldığında kimlik ve yakın dönemi yansıtan tarihsel ve kültürel mirasın Ankara bağlamında bütünüyle "Atatürk" ve "Cumhuriyet" temaları üzerinden kurgulandığı anlaşılabilir. İçeriden, "biz” vurgusu güçlü, çevreci duyarlıklarla çerçevelenmiş, benimsetici kaygıları güçlü bu söylemin Türk Milli Eğitim sisteminin temel ilkelerinin yanında öğretim programlarının uzak hedefleri ve temele aldıkları değerlerle de örtüştüğü söylenebilir.

Çanakkale'de isimli kitap Antik Truva kendine girilmesiyle başlar. Burada Mehmet'in ilk dikkatini çeken şey turistlerin fazlalığı olur. Harabelere yaklaştıkça kalabalığın arttığını gören Mehmet şöyle der: "Ay, ne çok turist var! Yaşasın! Yurdumuza bir sürü para bırakacaklar." Bunun üzerine annesi "şuna bakın hele, ne çok şey biliyor" değerlendirmesinde bulunur (s. 2). Az sonra "tahta atı" görürler. Mehmet sevinçle bağırır. Çünkü "en çok" onu merak etmektedir. Tahta atın merdivenlerinden çıkan Mehmet atın küçük penceresinden babasına el sallarken baktığı yerden manzarayı "harika" bulur, onların da gelip görmeleri gerektiğini söyler (s. 4). Anlatımın devamında aile Truva şehrinin yıkıntıları üzerinde oturur. Burada Mehmet tahta atın nereden geldiğini sorar. Annesi Truva kralının Paris adındaki oğlu ile çok beğendiği başka bir ülkenin kraliçesi arasında geçen ve Truva kendi etrafında bir takım olaylara yol açan hadiseler zincirini anlatır (s. 5-8). Anlatım kraliçenin askerlerinin tahta bir at marifetiyle şehre girerek Truvalıları "aldatması" ve kenti "ele geçirerek" her yerin "yakılıp yıkıldığı" notu ile bitirilir. Annesinin anlattığı bu söylence yol boyunca Mehmet'in aklını kurcalar ve Çanakkale boğazını feribotla geçerken Mehmet "savaş çok kötü bir şey" değerlendirmesinde bulunur (s. 9). Ancak bu esnada o, Şehitler Abidesi'ne bakmaktadır. Burada, 
görselle beraberindeki ifade arasındaki çelişkiye dikkat çekmek gerekmektedir. Truva Atı ve Kenti etrafında yaşananlarla ilişkisi bir ölçüde anlaşılabilir olsa da savaşın çok kötü bir şey olduğuna ilişkin değerlendirme Çanakkale Şehitler Abidesi bağlamında sorunludur. Nitekim Şehitler Abidesi'nin savaşın kötülüğü bağlamında değil, vatanı işgal etme ya da bir milleti tarihten silme teşebbüsü karşısında o milletin vatan savunmasındaki kahramanlığı bağlamında anlaşılması daha anlamlı olacaktır. Savaşın çok kötü bir şey olduğu yönündeki vurgunun yalnız başına kullanılması, Çanakkale'de yaşananların doğru anlaşılmasına yeterince hizmet etmeyebilir. Bu durum öğretim programlarındaki Çanakkale, Şehitlik, Milli Mücadele gibi değerlerin sunumu noktasında problem oluşturmaktadır.

Feribot kıyıya yaklaştıkça "kocaman bir taşın üstüne" yapılmış bir "Mehmetçik figürü" görürler. Yanında "Dur yolcu!..." şeklinde başlayan dizeler yer almaktadır. Annesi "yüksek sesle" okur. Bunu üzerine Mehmet "Anneciğim ne güzel okudun" der, annesi gülümser (s. 10-11). Görüldüğü gibi burada şiirin içeriğinden ziyade okuyuşun güzelliğine odaklanılmıştır. Böyle olsa bile "kocaman bir taş" üzerinde yazıldığı ifade edilen söz konusu şiirin "yüksek sesle" ve "güzel" okunmaya değer bulunarak bu şekilde okunması, ardından Mehmet tarafından beğenilmesi Çanakkale'yi anlama ve anlatma noktasında altı çizilmesi gereken bir husustur.

Devamında Çanakkale Şehitliği'ne varılır. Şehitler Anıtı karşılarındadır. Bu esnada anne, baba ve Mehmet Anıt'ın karşısında yüzleri anıta dönük biçimde, oldukça dik bir duruşla ona bakmaktadırlar. Çanakkale'de yaşananların hayal edilip hüzünlenildiği duygusal atmosferde Mehmet'in babası "İyi bak oğlum, bu anıt Çanakkale Savaşlarında ölen askerlerin anısına dikildi" der (s. 13). Ancak burada Anıt'ın söz konusu savaşlarda "ölen" kimleri temsil ettiği sorusu akla gelmektedir. Mesela Avustralya askerlerinin anısını da temsil etmekte midir? O zaman adı Şehitler Anıtı olabilir mi? Dahası işgal girişiminde bulunan Avrupalı devletlerin ordularından ölenler için "öldü" denebilirken bu tabir Müslüman askerler için söylenebilir mi? Bu durum yazarın nesnellik kaygılarıyla ilişkilendirilse bile Ankara örneğinde gösterilen duyarlıkların, içeriden ve öznel dilin burada göz ardı edilmesi önemli bir problemdir. Yaşamını yitiren Türk askeri için şehit tabirinin kullanılmaması her ne kadar kitapların hitap ettiği 6-7 yaş grubunun gelişimsel özellikleriyle ilişkilendirilebilse de "şehit" ve "ölüm" kelimeleri metnin farklı yerlerinde geçmektedir. Daha önce birçok kelimenin anlamını merak edip soran Mehmet burada pek ala "şehit" veya "şehitlik" kelimelerinin anlamlarını sorabilirdi. 
Kitabın ilerleyen sayfalarında Şehitler Anıtı civarında dikilen genç fidanlara dikkat çekilerek bunların çıkan bir yangında yanan eski ağaçların yerine dikildiğine değinilir. Doğa, tabiat ve ağaca ilişkin çevreci vurgular burada da yinelenir. Aile, kitabın sonunda İstanbul'a dönüş yolculuğunda Bolayır'a uğrar. Burada Namık Kemal'in mezarı ziyaret edilir. Anne Namık Kemal'in "ünlü bir şair" olduğundan söz eder. Bunun üzerine Mehmet de içinden "acaba ben de şiir yazabilir miyim" diye geçirir (s. 15). Mehmet kitabın son sayfasında yer alan günlüğe bu gün Truva ve Çanakkale'yi gezdiklerini, her yerin çok kalabalık olduğunu, birçok turist geldiğini ve "memleketimize" çok para bırakacaklarını bunun için çok sevinçli olduğunu yazar. Ayrıca Truva Atıyla ilgili yaşadıklarını, söz gelimi onun içine girdiğini ve çok beğendiğini ekler. Ancak onu "en çok" etkileyen şeyin Çanakkale Şehitleri Anıtı olduğunu belirtir. Ardından şunu ekler: "Her yerde savaşın çirkin yüzünü gördüm. Bir kez daha savaştan nefret ettim." Günlük Atatürk'ün şu ifadeleriyle biter: "Yurtta barış, dünyada barış." Kitabın sonunda yazarın Şehitler Anıtını Mehmet'i "en çok" etkileyen yer olarak sunmasının çocukların tarih bilinci ve kültürel miras edinimi bakımından önemli olduğunun altı çizilmelidir. Bununla beraber Çanakkale sunumunda öne çıkarılan ve "çirkin yüzü" "her yerde" görülen savaş söyleminin çocukların Çanakkale'de verilen Milli mücadele ve sergilenen kahramanlık örneğini gerektiği gibi anlayamamalarına yol açabileceği söylenebilir. Bu durum ilk yaşlarda oluşmaya ve gelişmeye başlayan biz bilinci ve kimlik algısı noktasında problem teşkil edebilir.

İstanbul'da isimli kitap kafilenin geziye gidilecek otobüse binmesiyle başlar. Mehmet'le Ayşegül yan yana oturur ve hemen sohbet etmeye başlarlar. Sınıfla birlikte gezi yapmanın keyifli olacağından bahsederler. Bu sırada öğretmen bu gün "ilk duraklarının” Gülhane Parkı oluğunu, orada kahvaltı yapıp çevreyi gezeceklerini belirtir ve "umarım bana verdiğiniz sözü tutarsınız, yaramazlık yapmazsınız" uyarısında bulunarak herkese "iyi eğlenceler" diler (s. 3). Ardından "kocaman" bir köprüden geçilir, geçerken "deniz" seyredilir. Manzara "çok güzel” bulunur. Gülhane Parkı'na gelindiğinde herkes acıkmıştır. Çınar ağaçlarının altındaki piknik masalarına koşulur. Burada herkes çantasındaki yiyecekleri çıkarır, birbirleriyle "paylaşırlar", öğretmenlerine de "ikram ederler" (s. 5).

Saray'a doğru giderlerken öğretmenleri onları durdurarak Gülhane Parkı'nın kendi çocukluğundaki durumundan bahseder, pek çok hayvanın olduğunu, örneğin maymunların muza bayıldıklarını söyler. Ardından o anı hayal etmelerini ister. Daha sonra Topkapı Sarayı'na gidilir. Hazine dairesi "çok güzel" bulunur. Burada "padişahların" taçlarını, tahtlarını görürler, "uzun süre" 
çevredeki eşyaları incelerler (s. 7). Ardından geçilen Porselen Dairesi de "çok güzel" şeklinde nitelendirilir. Mehmet burada mavi renkli porselenleri göstererek "bunların mavisi ne kadar güzel" der. Bunun üzerine öğretmeni o mavinin adının turkuaz olduğunu, bu rengi bir Türk ustanın bulduğunu bu nedenle mavinin bu tonuna turkuaz dendiği açıklamasını yapar. Görüldüğü gibi Topkapı Sarayı sunumunda, Anakara anlatımındaki gibi herhangi bir öğe ile "biz" dili üzerinden ilişki kurulmamış, içeriden bir dil geliştirilmemiştir. Bununla beraber Osmanlı mirasının çeşitli öğelerinden olumlu sıfatlarla söz edilmesi, Türk eksenli tonlara dikkat çekilmesi çocukların Milli manevi değerleri daha bütünlüklü anlaması bakımından anlamlı olabilir.

Buradan Arkeoloji Müzesi'ne geçilir. "Dünyanın pek çok ülkesinden gelen eserlerin" içinde "en ilginci"nin Mısır'dan getirilen mumyalar olduğu ifade edilir (s. 9). Arkeoloji Müzesinden sonra Çocuk Müzesine geçilir. Burada yer alan mağaralar görülmeye değer bulunur. Kendilerini zaman tüneline girmiş gibi hisseden çocuklar burada "çok eğlenirler." Sıra Yerebatan Sarnıcı'na geldiğindeyse öğretmenleri buranın eskiden su deposu olarak kullanıldığını vurgular (s. 11). Bir sonraki durak olan Ayasofya Müzesi'nde çok sayıda turistle karşılaşılır. Turistler kendilerine gülümseyerek bakarlar. Bu esnada bir rehber buranın müze olarak kullanıldığını söyler. Çocuklar duvardaki resimlere "hayranlıkla" bakarlar. Görüldüğü gibi gezinin bu bölümüne tamamen turistik bir hava hâkimdir. Bununla beraber yazarın Ayasofya'nın dini kimliği ya da yönü etrafında oluşan tartışmalara mesafeli durup onun bir müze olduğunu vurguladığı görülmektedir.

Gezinin sonlarına doğru Sultanahmet Camisi'ne geçilir. Caminin içi "çok güzel" bulunur. Caminin mavi, yeşil, beyaz İznik çinileriyle bezendiği vurgulanır. Avrupalıların Mavi Cami dedikleri caminin Unesco tarafından Dünya Miras listesine eklendiği de belirtilir (s. 13). Devamında Alman Çeşmesi önünde fotoğraf çektirilir. Bir sonraki durak Dikilitaş'tır. Dikilitaş üstündeki yazı, bilhassa kuş ve böcek figürleri çocukların dikkatini çeker. Öğretmen de Dikilitaş üzerinde kullanılan yazının "bizim bildiğimiz" harfler kullanılarak oluşturulmadığını, harflerin yerine sembollerin kullanıldığını belirtir. Kafile son olarak Beyazıt Meydanı'ndaki Sahaflar Çarşısı'na oradan da Matbaa Müzesi'ne gider. Bu arada öğretmen "Sahaf eski veya yeni kitap satan kişidir" açıklaması yapar (s. 15).

Kitabın sonunda Mehmet günlüğüne bu günkü gezilerinin "çok güzel" geçtiğini, birçok yer gezip çok şey öğrendiklerini, arkadaşlarıyla gezmenin de "çok zevkli" olduğunu yazar. Son olarak öğretmenlerine verdikleri sözü 
tuttuklarını, onu üzecek bir şey yapmadıklarını, öğretmenlerinin kendilerine teşekkür ederek bir dahaki sefere kendilerini Dolmabahçe Sarayı'na götüreceğini ekler.

İstanbul sunumunda özellikle Topkapı Sarayı, Sultanahmet Camii gibi Osmanlı dönemi eserlerinin farklı boyut ve yönleriyle sunumunda bütünlüklü ve tarihsel duyarlılığı güçlü yaklaşım dikkat çekmektedir. Bu anlamda örneğin Sultanahmet Camii için kullanılan ifadelerden Osmanlı mirasına duyarlı davranıldığı izlenimi edinilmektedir. Bu tasvir, çocukların tarihsel mirası bütüncül bir gözle okumalarına, daha doğru anlamalarına hizmet eder niteliktedir.

\subsection{Mekânların görsel tasviri}

Görselliğin okul öncesi ve ilkokul kuşağı çocukları için çok önemli olduğu bilinmektedir (Yavuzer, 2001). Bu guruptaki çocuklar görerek, bir kahramanı ya da öne çıkan karakterleri model alarak öğrenmeye meyillidirler. Sözü edilen çocuklar okudukları edebi eserlerin yazılarının yanında görselliğiyle de yoğunlukla ilgilenirler. Bu bakımdan edebi eserlerin görsel öğeler yoluyla oluşturdukları açık ve örtük mesaj üzerinden öğrencilerin değer yönelimlerini etkileyerek bilgi, duygu ve tutumlarında değişikliklere yol açtıklarını söylemek mümkündür.

Çalışmada incelenen Ankara'da isimli kitapta toplam 14 çizim/resim olup bunların 7'sı çeşitli kişi ya da durumları temsil eden heykellerden oluşmaktadır. Bunlardan 4'ü şehrin muhtelif yerlerinde bulunan Atatürk heykelidir. Ayrıca 1'i Aslanlı Yol'da bulunan aslanları merkeze almakta, 1'i Güven Anıtındaki heykelleri göstermekte, 1'i de gençlik parkında bulunan bir insan heykelini öne çıkarmaktadır. Bu öğeler görsellerin yaklaşık yarısını oluşturmaktadır. Geri kalan resimlerden 3'ü eski meclis binalarını, 2'si Ankara'ya giren ve ailenin içinde bulunduğu anlaşılan beyaz renkli otomobil ile etrafını çevreleyen Atatürk Orman Çiftliğini, 1'i kalınacak otelin giriş kapısı ile önünü, bu esnada kendileri ile kendilerini karşılayan kişiyi, 1'i Atatürk'ün mozolesini ve önünde resim çekilmekte olan aile üyelerini, 1'i Atatürk'ün özel eşyalarının sergilendiği salonu ve salonda bulunan ziyaretçileri, 1'i Atatürk'ün naaşını taşıyan üzeri Türk bayrağıyla örtülü top arabasını ve o esnada orada bulunan ziyaretçileri göstermektedir. Çalışma kâğıdında ise sadece bir görsele yer verilmiş olup o da "Mehmet, Ankara'da önce nereyi gördü?" sorusunun seçenekleri yanında verilen Anıtkabir resmidir.

Kitaptaki ilk ve ikinci görselde Mehmet ve ailesinin içinde bulunduğu beyaz renk otomobilin Atatürk Orman Çiftliği'nden şehre girişi görülmektedir.

ÇÜiFD, 2018, cilt: 18, sayı: 2, ss. 1070-1101. 
Görsellerde oldukça yeşil, düzenli ormanlar arasında farklı yapılar görünmekte ve otomobil ise yeşil alanlar içerisinde kıvrımlı şekilde ilerleyen yolda seyretmektedir. Resimlerle birlikte Atatürk'ün de "bizim gibi" çevreci olduğu vurgulanmış, Atatürk Orman Çiftliği'nin kuruluşuna ilişkin tartışmalara yer verilmiştir. Görüldüğü gibi burada görseller ve taşıdıkları anlam Atatürk ekseninde 'biz'imle ilişkilendirilmektedir. Burada biz vurgusunun ve bu vurgu etrafında yapılandırılmaya çalışılan kimliğin en önemli unsuru Atatürk ve onun çevreciliği olduğu söylenebilir.

Sonraki görselde Neva Palas isimli otele giriş yapmakta olan aile bireyleri ile onları otelin kapısında karşılayan görevli görülmektedir. Kitapta yer alan dördüncü görselde Aslanlı Yolda ilerleyen aile bireyleri ve Anıtkabir'e giden diğer ziyaretçiler yol kenarı boyunca yerleştirilen iki aslan heykelini merkeze alacak şekilde gösterilmiştir. Oldukça büyük çizilen heykellerin önünde, üniformalı bir muhafız silahıyla beklemekte ve Mehmet ona bakmaktadır. Atatürk'ün mozolesinin bulunduğu salonu resmeden bir sonraki görselde anne, Atatürk'ün mozolesini arkalarına almış şekilde duran Mehmet ve babasının fotoğrafını çekerken görülmektedir. Bir sonraki görselde aile bireyleri diğer ziyaretçilerle birlikte Atatürk'ün özel eşyalarının bulunduğu salonda görülmekte, aile bu esnada Atatürk'e ait haki subay üniformasını incelemektedir. Bir sonraki görselde aile bireylerinin yine Anıtkabir içerisinde, bu sefer Atatürk'ün naaşını taşıyan, üstü Türk bayrağıyla örtülü bir top arabasına baktıkları ve dikkatle inceledikleri görülmektedir.

Anıtkabir ziyaretinin ardından Ulus Meydanı'na geçilmiştir. Görselde Ulus Meydanı'nda bulunan Atatürk Heykeline bakan aile üyeleri ile diğer ziyaretçiler görülmektedir. Mehmet'in babası bu esnada görsele yönelerek "bol bol" fotoğraf çekmektedir. Burada gerek heykel gerekse etrafındaki yapılar ile ziyaretçilerin oldukça dikkatli ve canlı tonlarda çizilmeye çalışıldığı anlaşılmaktadır. Bilindiği gibi söz konusu heykelin çevresinde, daha alt düzeyde farklı pozisyonlarda üç asker heykeli bulunmaktadır. İncelenen görselde ellerini yukarıya doğru açıp Atatürk'ü işaret eden, onu yücelten duruşuyla pozisyon almış askerin heykele ilave edilmiş olması dikkat çekicidir. Bir sonraki görselde ise aile bireylerinin karşıdan bakarak izledikleri, ön tarafında yoldan geçen insanlarla araçların görülebileceği şekilde bir mesafeden çizilen Birinci Meclis binası görülmektedir. Ardından gelen diğer görselde ise bu sefer söz konusu binanın içi görülmektedir. Görselde aile bireyleri meclisin ön tarafına, Atatürk heykeli ve Türk Bayrağıyla bütünleştirilmiş, sahne ve kürsülerin bulunduğu yöne doğru bakmaktadırlar. Gerek meclisin dışını gerekse içini gösteren görselin söz konusu binaya ilişkin metinde geçen "eski”, "içindeki her şeyin 
olduğu gibi korunduğu", "ilk milletvekillerinin oturdukları sıraların hâlâ yerinde" olduğuna ilişkin ifadeleri destekler nitelikte çizildiği görülmektedir. Bu anlamda görsellerle metin birbirini desteklemektedir. Sonraki görselde aile üyeleri İkinci Meclis Binası önünde görülmektedir. Aile bireylerinin önünde meclisin ve tarihi binaların anlam ve önemi üzerinde konuştukları bu İkinci Meclis Binasını gösteren resmin oldukça düzgün, renkli, dikkat çekici bir üslupla çizildiği görülmektedir.

Ankara'da isimli kitapta sonraki iki görselden ilki Güven Park'taki Güven Anıtı'nı, diğeri ise Resim Heykel Müzesi önündeki heykeli göstermektedir. İlkinde aile anıtı seyretmekte, ikincisinde ise heykel "incelenmekte" baba ise "yine" "bol bol" fotoğraf çekmektedir. Ankara'da yer alan son görselde aile bu sefer eğlenmek amacıyla gittikleri Gençlik Parkı'nda görülmektedir. Parkta anne baba şelaleyi ve ileride oluşan gök kuşağını izlerken, Mehmet ise yakınlarda bulunan bir kadın heykelini dikkatle incelerken görülmektedir. Heykel koyu yeşil bir tabii doku üzerine çizilmiş ve sayfanın merkezine oturtulmuştur. Ankara sunumunda pek çok görselde öne çıkarılan heykel temasının eğlenme amacıyla gidilen bir parkta tekrar edilmesi, yazarın Ankara'ya bakışı ve buradan hareketle öne çıkarmaya çalıştığı kültürel duyarlıklarla ilişkilendirilebilir. Ankara'yı sadece Cumhuriyet sonrası dönemin seküler değerlerine indirgeyerek tasvir etmek kültürel mirasın aktarımı bakımından sorun oluşturacağı gibi çocukların bir şehir üzerinden edineceği mekân ve kimlik tasavvurunda da ciddi problemlere yol açabilecektir. Dahası bu söylem Atatürk ve onunu manevi mirasının eksik ya da yanlış anlaşılmasına da zemin hazırlayabilir.

Çanakkale'de isimli kitapta ise 14 çizim kullanılmıştır. Bunlardan 7'si Truva kenti ve Truva Atı'yla, geri kalanlardan 6'sı Çanakkale kara ve deniz savaşları ve Türk şehitliklerinde bulunan muhtelif yapılarla, 1'i ise Namık Kemal'in kabrinin ziyaretiyle ilgilidir. Truva kazı alanlarından birinin yer aldığı ilk görselde aile bireyleri kendi aralarında turistlerin bıraktıkları döviz hususunda sohbet etmekte, çevredeki diğer ziyaretçiler de alanı seyretmekte ya da incelemektedirler. İkinci görselde ise aile bireylerinin, Mehmet'in "en çok merak ettiği” Truva Atı'na doğru yöneldikleri ve Mehmet'in elini o yöne doğru uzattığı görülmektedir. Ayrıca Atın önünde de antik kentten kalma çeşitli maddi unsurlar görülmektedir. Üçüncü resimde Mehmet bu sefer Truva Atı'nın penceresinden ailesine el sallamakta onların da gelip "harika" olan manzarayı görmelerini istemektedir. 3-6. resimler Truva Atı etrafında gelişen tarihsel olayların anne tarafından anlatılmasını tasvir eden, genelde söz konusu atın ve onun çevresinde gerçekleşen olaylarla ilgili olarak asker, sur ve gemi gibi görsellerin

ÇÜiFD, 2018, cilt: 18, sayı: 2, ss. 1070-1101. 
yer aldığı çizimlerdir. Oldukça özenilerek çizildiği anlaşılan bu görsellerin kitabın başından beri yazarın Çanakkale'ye bakışı ve bu şehrin tarihsel-kültürel mirasına ilişkin kaygılarını besleyen genel anlayışla örtüştüğü söylenebilir.

Truva bölgesi gezilmiştir. Bundan sonraki çoğu resim feribotla geçilen tarihi Gelibolu yarım adası, yani Çanakkale kara ve deniz savaşlarındaki en önemli mücadelelerin yaşandığı bölgeyle ilgilidir. Kitapta 7 numaralı görsel Çanakkale Boğazı'nda seyreden, ailenin de içinde bulunduğu feribotta Şehitler Anıtı'na doğru bir projeksiyon içermektedir (Bkz. Resim 1). Aile bireyleri feribotun güvertesinden dışarıyı seyretmektedirler. Mehmet ise o esnada annesinin Truva olaylarıyla ilgili anlattıklarının etkisiyle (Çünkü Çanakkale savaşlarıyla ilgili henüz kendisine bir şey anlatılmamış ya da gösterilmemiştir.) savaşın "çok kötü bir şey" olduğunu düşünmektedir. Tam bu esnada uzaklardan Şehitler Anıtı görülmektedir. Burada savaşın çok kötü bir şey olduğuna ilişkin düşünceyle Şehitler Anıtını ufka yerleştiren görsel birlikte kullanılmıştır. Bu durum yazılı ve görsel anlatım arasında çelişki oluşturmaktadır. Zira savaş kelimesinin Truva Atı etrafında gelişen olaylarla, söz gelimi şehrin yakılıp

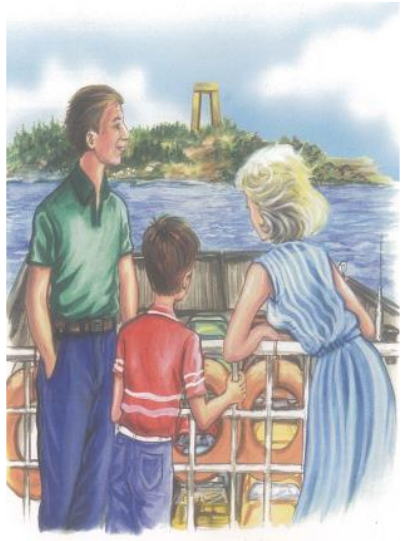

Resim 1: Ufukta Şehitler Anıtı yıkılması, yağmalanması gibi olgularla kolayca ilişkilendirilebileceği söylenebilir. Ancak Şehitler Anıtı yakıp yıkmayı, yağmayı değil öncelikle işgale, yakıp yıkmaya direnci, kahramanlığı, milli birlik beraberliği, vatan savunmasını simgelemektedir. Bunların bir tarih kitabında savaş kavramıyla daha kolay ilişkilendirilebileceği söylenebilir. Oysa çocuklara değer yönelimlerinin oluşmaya başladığı bir dönemde meselenin başka kavramlarla izah edilmesi daha pedagojik bir yaklaşım olabilir. Burada anıtı ufukta gören Mehmet'in savaş olgusunu yanında başka şeyleri de düşünmesi ya da en azından ebeveynin başka şeyler söylemesi beklenirdi.

Bir sonraki görselde boğazda seyreden feribotun kıyıya yaklaşmaya başladığı, bu esnada annenin "yüksek sesle" karşı yamaçlarda "kocaman bir taşın üstünde" bulunan "Dur yolcu!..." şeklinde başlayan şiiri okuduğu anlaşılmaktadır. Mehmet annesinin şiiri güzel okuduğunu belirtir, annesi gülümser. Bir sonraki görsel Şehitler Anıtı ve onun önünde anıta dönük bir vaziyette durup anıtı inceleyen aileyi göstermektedir. Anıt oldukça heybetli çizilmiş olup zeminden yanlara doğru farklı renk çiçeklerle bezenmeye çalışılmıştır. Baba yalnız başına, anne ile Mehmet ise birlikte durmakta, annenin eli Mehmet'in omzu üstünde, Mehmet ise eli alnında anıtın tepesine doğru bakmaktadır. Anıtın heybetli duruşu ile o esnada babasının "İyi bak 
oğlum, bu anıt Çanakkale Savaşlarında ölen askerlerin anısına dikildi" şeklindeki ifadeleri arasındaki irtibatsızlığa dikkat çekmek gerekmektedir. İfadenin anlamına ilişkin değerlendirme daha önce yapılmıştı. Bununla beraber, anıttaki heybetin neyle ilişkilendirildiği ya da neyin heybetini yansıttığı metnin bütünü düşünüldüğünce yeterince açık ve anlaşılır değildir. Kitapta anıtla ilgili söylenen "Anıt sanki gelip geçen gemileri selamlıyordu. O günleri hayal edip hüzünlendiler" ifadeleri ile Mehmet'in son sayfada bulunan günlüğüne yazdığı "Beni en çok Çanakkale Şehitleri Anıtı etkiledi" şeklindeki notu anıtla metin arasında oluşan anlam belirsizliğini gidermeye yetmemektedir denebilir.

Bir sonraki görselde Çanakkale deniz savaşlarının bir temsili verilmiş olup, yukarıda kara bulutlar, boğazda ise çarpışan irili ufaklı savaş gemileri görülmektedir. Görsele ilişkin herhangi bir açıklama bulunmamakla birlikte, burada kullanılan renk, desen ve dokular Çanakkale deniz savaşlarının niteliği hakkında okura önemli ipuçları verir niteliktedir. Anıtın hemen yanındaki genç fidanlara dikkat çekmekte olan bir sonraki görsel ile birlikte bu fidanların bir süre önce çıkan yangının ardından dikilen fidanlar olduğuna ilişkin bir açıklamaya yer verilmiştir. Kitapta yer alan son görselde aile bireylerinin İstanbul dönüşü Bolayır'da bulunan Namık Kemal'in kabrini ziyaret ettikleri görülmektedir (Bkz. Resim 2). Bu esnada anne Namık Kemal'in ünlü bir şair olduğunu belirtmekte Mehmet de içinden "acaba ben de şiir

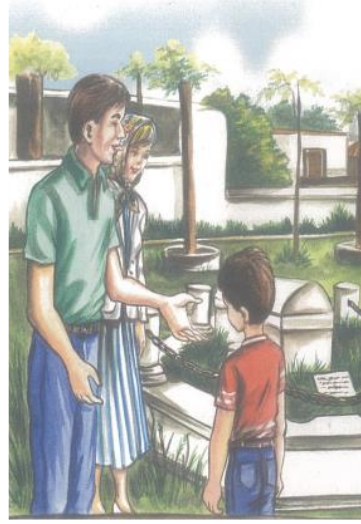

Resim 2: Namık Kemal'in kabrini ziyaret yazabilir miyim" diye geçirmektedir. Görselde dikkat çekici olan annenin başörtülü resmedilmiş olmasıdır. Kabir ziyareti esnasında saygı gereği böyle bir uygulamaya yer verilmiş olduğu düşünülebilir. Daha önce ne Atatürk ve İnönü'nün kabirlerinde ne de Gelibolu Yarımadasında ziyaret edilen şehitlikler için böyle bir uygulamaya yer verilmemiş olduğunun altı çizilmelidir. İncelenen üç kitapta da herhangi bir başörtülü figür olmadığı halde, başörtüsünün sadece kabir ziyaretinde kullanılabilen bir araç olduğuna ilişkin anlayışın Türkiye'nin toplumsal gerecekleri ile ne derece örtüştüğü yeterince açık değildir. Bununla beraber kabir ziyareti gibi uygulamalar, kitabın öğretim programlarında öne çıkarılan sılairahim gibi değerlerle irtibatını göstermesi bakımından anlamlıdır.

Üçüncü çalışma olan İstanbul'da isimli kitapta ise 14 çizim kullanılmıştır. Bunlardan 2'si yolculuğun geçtiği aracın içini, 1'i İstanbul boğazı ile Boğaz Köprüsü'nü, 2'si Gülhane Parkı'nı, 2'si Topkapı Sarayı'nı, 2'si Arkeoloji Müzesi'ni, 1'i Yerebatan Sarnıcı'nı, 1'i Ayasofya Müzesi'ni, 1'i Sultanahmet Camii'ni, 1'1 Alman Çeşmesi'ni, 1'i de Sahaflar Çarşısı'nı içindeki ziyaretçilerle 
birlikte göstermektedir. Görsellerin denge ve dağılım olarak metinle uyumlu olduğu söylenebilir.

İstanbul'da isimli kitapta yer alan ilk çizim yolculuğun yapıldığı otobüste yan yana oturan ve birbirleriyle sohbet eden Mehmet ile Ayşegül'ü göstermektedir. Bu esnada Ayşegül'ün elinde içinde fotoğraf makinesi olduğunu düşündüren küçük bir çanta bulunmaktadır. İkinci resim yine aracın içini göstermekte olup öğretmen önde ve ayakta durmakta, öğrencilerine yolculuk güzergâhı hakkında bilgiler vermekte, gezi boyunca uyacakları bir takım kuralları hatırlatmaktadır. Üçüncü görselde kafile "kocaman" bir köprüden denizi seyrederek geçmekte bu esnada manzaranın "çok güzel olduğu" ifade edilmektedir. Görselde boğaz köprülerinden biri etrafındaki manzara ile birlikte tasvir edilmektedir. Sonraki görselde kafile, Gülhane Parkı'nın iri ağaçlarının gölgelediği yeşil bir örtü altında piknik yaparken görülmektedir. Aynı ortamla ilgili olan sonraki görselde ise parkın öğretmenin çocukluğundaki durumu, içerisindeki hayvanlarla (maymun vb.) birlikte resmedilmiş, öğretmen tarafından o günlerin hayal edilmesi istenmiştir. Altıncı görselde kafilenin Topkapı Sarayı/Hazine dairesini gezdiği görülmektedir. Burada "padişahların" taçları, tahtları görülerek "uzun süre" çevredeki diğer eşyalar incelenir. Devamındaki görselde bu sefer Porselen dairesinin gezilme anı porselen olduğu anlaşılan bir takım eşyaların bulunduğu vitrine bakan çocuklarla birlikte resmedilmiştir. Her iki dairede de çocukların incelenen eşyalara dikkatle baktıkları, canlı renklerin kullanıldığı, şekillerin düzgün ve organize biçimde sayfaya işlendiği görülmektedir. Bu durum İstanbul ve içerdiği tarihsel sembollerin doğru anlaşılması bakımından önemlidir. Topkapı Sarayı'nın Porselen Dairesine varıncaya kadar gezilmesi ve çeşitli yönleriyle görselleştirilmesi yazarın İstanbul'daki özellikle Osmanlı mirasını daha etraflı tanıtma kaygısına ışık tutacak niteliktedir.

Bir sonraki görsel Arkeoloji Müzesinin içini göstermektedir. Kafile bu esnada "Mısır'dan getirilen" ve zeminde uzanan beyaz renkteki iki mumyayı dikkatle incelemektedir. Ardından gelen görselde gezinin bir sonraki durağı olan Çocuk Müzesi görülmektedir. Görselde mağaralar ve önlerinde yer alan bir "mağara adamı" ile onları inceleyen çocuklar görülmektedir. Kafilenin burada çok eğlendiği belirtilmektedir. Bir sonraki görselde kafile Yerebatan Sarnıcı'nın içini incelemekte, bir sonrakinde ise "Ayasofya Müzesi" ziyaret edilmektedir. Bu esnada orada bulunan bir rehber tarafından buranın "müze olarak kullanıldığı" özellikle vurgulanır. Bu esnada çocukların duvardaki "resimlere" hayranlıkla baktıkları ifade edilir. Buradaki görsel, Ayasofya'nın çoğunlukla üst bölümlerinde, özellikle kubbe içlerinde yer alan Hıristiyanlığa ait ikonografik 
öğeleri değil, cami içi tezyinatında sıklıkla kullanıldığını bildiğimiz yeşil renkli "Ali" ve "Ömer" levhalarını öne çıkarmaktadır. Müze vurgusuyla beraber görselde sözü edilen İslam dini ile ilgili levhaların belirgin biçimde öne çıkarılmış olması, Ayasofya özelinde İstanbul'un taşıdığı tarihsel ve kültürel mirasın derinliğini, ama özellikle İslam'ın etkilerini yansıtması bakımından anlamıdır (Ayrıca bkz. Kaya, 2012: 14-17).

İstanbul'da bir sonraki görselde Sultanahmet Camii'nin içinin gezildiği görülmektedir. Caminin içinin "çok güzel” bulunduğuna daha önce de değinilmişti. Görselde çocuklar mavi, yeşil, beyaz İznik çinileriyle bezenen iç yüzeyleri incelemektedirler. Burada caminin içinin oldukça dikkatle çizildiği, öğrencilerin çinilerdeki figürleri dikkatle inceledikleri görülmektedir. Sonraki görselde çocukların Sultanahmet Camii yakınlarında bulunan Alman Çeşmesi önünde fotoğraf çekilme anları görülmektedir. Kitapta yer alan son görsel ise Beyazıt Meydanında bulunan Sahaflar Çarşısı'nda çocukların öğretmenleriyle birlikte bir sahafta bulunan kitapları inceleme anlarını konu edinmektedir. Ayrıca etkinlik çalışma yaprağında yer alan bir soruda "hangisi dünya miras listesine alınmıştır?" şeklinde bir soru yöneltilmiş ve seçeneklerde Sultanahmet Camii ile Alman Çeşmesi'nin görselleri verilmiştir. Sultanahmet Camiinin yazılı ve görsel olarak özenle resmedilmeye çalışılması, içinin tezyinatıyla birlikte "çok güzel" bulunması, ayrıca gerek metinde gerekse sorularda dünya kültür mirasına alındığının yine görselleştirilerek verilmesi kültürel miras öğretimi bağlamında anlamlı ve önemlidir.

\subsection{Etkinlik örnekleri}

İncelenen kitapların her birine öğrencilerin okuduğunu anlayıp anlamadıklarına ilişkin belli ölçme değerlendirme unsurlarını içeren çalışma kâğıtları eklenmiştir. Bu etkinliklerin metinde öne çıkarılan mekânlar ile mekânların görsel ve yazılı anlatımlarıyla ilişkisi önemlidir.

Ankara'da isimli kitabın değerlendirme kâğıdının ön yüzünde her biri ikişer seçenekten oluşan altı soru yer almaktadır. Bu sorularda sırasıyla Mehmetlerin Ankara'ya varış saati, Mehmet'in Ankara'da ilk gördüğü yer, Mehmet'in Ankara'da en çok görmek istediği yer, Aslanlı Yol'un nerede olduğu, Mehmet'in neredeki Atatürk anıtını çok beğendiği, Mehmetler eğlenmek için nereye gittikleri sorulmuştur. Çalışma kâğıdının arka yüzünde yer alan 7, 8 ve 9 numaralı açık uçlu sorularda sırasıyla kitaptaki ana karakterlerin kimler olduğu, Mehmetlerin Gençlik Parkında neler yaptıkları ve Mehmet'in kimlerin kötü gün dostu olduğunu söylediğine dair sorulara yer verilmiştir. 10 numaralı etkinlik altı kelimeden/sorudan oluşan bir bulmaca olarak düzenlenmiştir. 
Burada sırasıyla "Büyük, gösterişli mezar; İkinci cumhurbaşkanımızın adı; Atatürk' ün anıt mezarının adı; Mehmet' in bindiği bir oyun aracının adı; Sanat ve bilim eserlerinin sergilendiği yer ve Günü gününe tutulan hatıra" sorularına yer verilmiştir. Bulmaca tam ve doğru şekilde doldurulduğunda saklı sözcük olarak Atatürk kelimesine ulaşılmaktadır. Görüldüğü gibi çalışma kâğıdı, kitabın temel kaygıları, kapak tasarımı, konuların işlenişi, görsel ve yazılı anlatımı bağlamında oluşan olay örgüsüyle örtüşmektedir.

Çanakkale'de isimli kitaba ilişkin hazırlanan çalışma kâğıdının ön yüzünde her biri üçer seçenekli altı test sorusu bulunmaktadır. Sorulardan ilki Mehmetlerin Çanakkale'de ilk gezdikleri yeri, ikincisi ailenin Tahta Atı nerede gördüğünü, üçüncüsü Mehmet'in babasına nereden el salladığını, dördüncüsü kitapta anlatılan efsaneye göre kraliçeyi kaçıran kişinin kim olduğunu, beşincisi Mehmetlerin İstanbul'a dönerken nereyi ziyaret ettiklerini sormaktadır. Altıncı ve son soru çoktan seçmeli olup "Hangisini görmek Mehmetleri hüzünlendirdi?" şeklindedir. Seçeneklerde ise sırasıyla Şehitler Anıtı, Truva Atı, Truva Kendi kazı alanını gösteren görseller yer almaktadır. Anlaşıldığı kadarıyla soruda Şehitler Anıtının hüzünlendirici etkisinin bulunması istenmektedir. Zira metindeki kurgu bu yöndeydi. Yani anıt hüzünlendirici bir görsel olarak kodlanmıştır. Kitap boyunca "Çanakkale" ve "savaş" ilişkisinin anlaşılma biçimi düşünüldüğünde sorunun soruluş nedeni ve biçimi daha iyi anlaşılmaktadır. Burada Truva ekseninde değil, Gelibolu Yarımadası ve Şehitler Anıtı ekseninde hüzünlenilmesi istenmekte ya da beklenmektedir. Bu kavrayışın öğretim programlarında çeşitli biçimlerde işarete dilen, Türkçe öğretim programında ise yer öğretilmesi zorunlu değerler arasında zikredilen "Çanakkale”, "Şehitlik", "Vatan" ve "Milli Mücadele" gibi değerlerin doğru anlaşılması noktasında ne anlama geldiği ayrıca tartışılmalıdır.

Çalışma kâğıdının arka yüzünde Truva Atı efsanesine ilişkin belli olayları yansıtan cümleler verilmiş ve bunların oluş sırasına göre numaralandırılıp sıralanması istenmiştir. Her bir cümlenin önündeki kutucukta yer alan harf saklı sözcük kısmına yazıldığında Truva Atı kelimesine ulaşılmaktadır. Görüldüğü gibi çalışma kâğıdının ön ve arka yüzü büyük ölçüde Truva antik kenti ve özellikle Truva Atı Efsanesi ile ilişikli sorulardan oluşturulmuştur. Sorular bağlamında oluşan bu muhteva kitabın yazılı ve görsel anlatımıyla örtüşmektedir. Tıpkı metnin konularının dağılımındaki sistematikte olduğu gibi, çalışma kâğıdında verilen yedi sorudan yalnızca biri Çanakkale, Vatan ve Şehitlik bağlamındadır. Her ne kadar Namık Kemal'in mezarının ziyaretiyle ilgili de bir soru sorulmuş olsa bile onun kişiliği ve şairliği ile vatan arasında metinde herhangi bir ilişki kurulmamıştır. Sonuç olarak Çanakkale gezisinin de tıpkı 
İstanbul gezisinde olduğu gibi turistik kaygılarla yapıldığı, bir şehir olarak Çanakkale tasvirinin vatan, şehitlik, milli mücadele gibi değerlerle yeterince ilişkilendirilmeden, hatta yer yer yanlış ilişkilendirilerek sunulduğu anlaşılmaktadır. Bu tasvir gerek yazılı gerekse görsel anlatımla örtüşecek şekilde ölçme değerlendirme etkinlikleriyle de desteklenmiştir.

İstanbul'da isimli kitabın çalışma yaprağının ön yüzünde, doğru yanlış türünde iki seçenekli altı soruya yer verilmiştir. Soruların ilk beşinde seçenekler yazıyla, sonuncusunda ise görselle verilmiştir. Sorular sırasıyla Mehmet'in İstanbul'u kimlerle gezdiğini, Çocukların nerede kahvaltı ettiklerini, Ayasofya Müzesi'nden sonra nereye gidildiğini, Yerebatan Sarnıcı'nın eskiden ne olarak kullanıldığını, verilen resimlerden hangisinin Dünya Miras Listesi'ne alındığını sormaktadır. Çalışma kâğıdının arka yüzünde yer alan ilk soru şöyledir: "Çocuklar, yanda resmini gördüğünüz yerde ne yaptılar?" Resim ‘Şeytan Ayağı” levhası yazılı bir tabelanın işaretlediği alanı göstermektedir. Kafilenin kahvaltı yaptığı yer Gülhane Parkında olduğuna göre resmin burayla ilgili olduğu düşünülebilir. Ancak metinde resmin karşılığı olan herhangi bir bilgi yer almamaktadır.

Arka yüzde yer alan diğer etkinlik bir çengel bulmaca örneği olup 5 sorudan oluşmaktadır. Sorulardan ilki çocukların Topkapı Sarayı'nda gördükleri eşyalardan birinin adını, diğeri çocukların seyahat ettikleri taşıtın adını, bir diğeri Mehmet'in otobüste birlikte oturduğu arkadaşının adını, diğeri maymunların yediği bir yiyeceğin adını ve sonuncusu da kitapta görselleri de verilen mumyaların getirildiği ülkenin adını sormaktadır. Bulmaca doğru şekilde çözüldüğünde hangi kelimeye ulaşılacağı anlaşılamamıştır. Sorular genel olarak kitabın İstanbul sunumuna ilişkin temel kaygıları ile konu bütünlüğü, yazılı ve görsel anlatımda öne çıkarılan hassasiyetler ile uyumlu olup açık, anlaşılır sorulardır.

\section{Sonuç}

$\mathrm{Bu}$ çalışmada ilkokula yeni başlayan çocukların okuduğunu anlama becerilerini geliştirme amacıyla hazırlanan ve Ankara, İstanbul ve Çanakkale'ye yapılan gezileri konu edinen üç kitaptaki şehir tasavvuru, Türkçe öğretim programlarında işlenmesi zorunlu kabul edilen kültürel-tarihsel miras ve bununla yakından ilişkili şehitlik, Milli kültür ve kimlik, Çanakkale vb. değerlerin eğitimi bağlamında ele alınmaya çalışılmıştır. Şehirleri belli yönleriyle sunmanın, erken dönemlerde çocukların değer yönelimleri ile değerler eğitimi adına önemli olduğu söylenebilir. Nitekim insan gelişiminin temelleri yaşamın ilk yıllarında atılmaktadır. 
Çalışma kapsamında incelenen her üç kitapta kültürel miras, üç büyük şehrin yazılı ve görsel tasviri üzerinden belli yönleriyle konu edilmiştir. Ankara'da tamamen Cumhuriyet sonrasına özgü motiflere odaklanılmış, Osmanlı ve Selçuklu tarihi bir yana, Cumhuriyet sonrasının dini yapılarına da yer verilmemiştir. İstanbul'da tarihsel kronolojiye dikkat edilerek İstanbul'un Osmanlı öncesi, Osmanlı ve Osmanlı sonrası kültürel mirasına birlikte yer verilmeye çalışılmıştır. Çanakkale'de ise kitabın gerek yazılı gerekse görsel muhtevasının yanında etkinlik örneklerine de büyük ölçüde Truva bölgesine odaklanılmış, Çanakkale'nin yakın tarihiyle diğer maddi manevi kültürel mirası öncekine oranla daha az işe koşulmuştur.

Ankara'nın metinde öne çıkarılan metaforlar üzerinden, manevi yönleri budanmış bir tasvirle okura sunulmasının değer yönelimleri açısından bakıldığında çocukluk döneminde şehrin, kültürel mirasın, Atatürk ve Milli mücadelenin yanlı/ş ya da eksik anlaşılmasına yol açabileceği söylenebilir. Çanakkale ve İstanbul bağlamında kültürel mirasın daha bütünlüklü, tarihsel olarak belli bir süreklilik ve derinliği yansıtacak şekilde sunulmasının değerler eğitimi ve çocukluk dönemi değer yönelimleri bağlamında anlamlı olduğu söylenebilir. Eserlerde kullanılan birçok görselin açık, anlaşılır ve dikkat çekici renk, doku ve desenlerle yapılandırılması görsel öğrenmelerin güçlü olduğu bu dönem çocuklarının gelişimi açısından anlamlıdır. Bununla birlikte kitap kapaklarındaki görsel öğeler ile içerikte kullanılan kimi resimlerde kronolojik bütünlük ve tarihsel tutarlık yanında metin-görsellik uyumu bağlamında da yer yer sorunlu yönler barındırdığı görülmüştür. Söz gelimi İstanbul'da isimli çalışmanın kapağında Dikilitaş'ın en öne, cami ve onu temsil eden minare resminin en arkaya düşürülmesi, fotoğraf makinesiyle bu ortama turistik bir hüviyet kazandırılması İstanbul'un temsil ettiği değerler ile bir bütün halinde anlaşılması açısından problem teşkil edebilir. Kapakta dikkat çekici biçimde öne çıkarılan Dikilitaş figürünün İstanbul'u ve onun barındırdığı tarihsel-güncel değerleri ne derece kuşattığı tartışmaya açıktır.

Milli kimlik değeri bağlamında kitapların diline, özellikle biz eksenli anlatılara bakıldığında da çeşitli sorunların olduğu göze çarpmaktadır. Söz gelimi kitaplarda anlatılan ya da öne çıkarılan mekânların sunumuyla ilişkilendirilen "biz" söylemi her üç kitap birlikte düşünüldüğünde dengeli ve tutarlı değildir. Truva ve Çanakkale şeklinde iki bölümde inşa edilen Çanakkale'de isimli kitapta biz vurgusu sadece gelen turistlerin bırakacağı meblağ bağlamında "memleketimiz" vurgusuyla yapılmıştır. Gelibolu yarımadasındaki mekânların anlatımında biz vurgusu Ankara'da olduğu gibi sadece Atatürk üzerinden "Ata'mız" vurgusuyla yapılmıştır. Bunun dışında 
şehitlik, milli birlik, vatan, kahramanlık vb. herhangi bir öğe üzerinden biz vurgusu yapılmamıştır. İstanbul anlatımında kullanılan padişah, cami, Türklük gibi kavramlarla biz dili üzerinden herhangi bir irtibat kurulmamıştır. Metinlerde bunların "bizimle" ilişkili olduğuna, bizim kültürel mirasımız olduğuna ilişkin güçlü ve sarih vurgulara rastlanılamamıştır. Bu durum eserlere konu edilen şehirlere ve bu şehirlerin taşıdığı değerlere bakışla ilişkilendirilebilir.

Yukarıdaki kaygıdan yala çıkılarak kitapların dil ve anlatımına daha yakından bakıldığında, Çanakkale ve İstanbul'un bir turist gibi gezildiği, izlenimlerin çoğunlukla dışarıdan bakışla, bir ziyaretçi edasıyla aktarıldığı söylenebilir. Az önce ifade edildiği gibi bu iki ilin "biz/im/le" en önemli ilgisi "vatanımıza" para bırakılan yerler olmalarıdır. Ayrıca bu illere yapılan gezilerin eğlence tonu hayli güçlüdür. Örneğin İstanbul gezisi "iyi eğlenceler" temennileriyle başlar. Bununla beraber İstanbul'a yapılan gezinin ayrıca öğretici olduğu vurgulanmıştır ki bu kültürel mirası doğru anlama bakımından önemli bir detaydır. Ne var ki Ankara'da durum böyle değildir. Ankara'da dil ve anlatımda nesnel ve dışarıdan bir betimleme ya da tanıtımdan ziyade öznel ve içeriden, "biz" dili ile bir yükleme ve ortak bir değer inşa etme kaygısı öne çıkmaktadır. Ankara'da ilk görülmesi gereken, en çok görülmesi arzulanan, en fazla heyecan uyandıran, çok güzel bulunan, uzunca bir süre gözlerin ayrılamadığı, iyi bakılması gereken, dolayısıyla bol bol fotoğraflanan mekânlar sadece Cumhuriyet sonrası dönemi temsil eden unsurlar ve bunların yer aldığı muhtelif mekânlardır. Bu çalışmada incelenen diğer kitapların hiçbirinde "biz" dili üzerinden ortak değer inşa etme kaygısı bu derece belirgin ve güçlü değildir. Bu kaygı Ankara'da "heykel" gibi oldukça radikal, görsel bir metaforla da pekiştirilmiştir. Bu metafor zaman zaman "olağanüstü" bulunmuş, "hayranlıkla" izlenmiş ve "bol bol" fotoğraflanmıştır. Çanakkale ve İstanbul'u bu derece belirgin kılan ve bol bol fotoğraflanmayı hak eden herhangi bir sembolik değer bulunamamıştır. Oysa her iki şehirle adeta özdeşleşmiş mekânlar, yapılar, isimler, semboller, hatta renkler bulunmaktadır (Cançelik, 2014: 28-43).

Yukarıda ortaya konan şehir tasavvuru kimi yönleriyle geçmişe, geleneğe, söz gelimi dine dair değerlere mesafeli durma tavrıyla ilişkilendirilebilir (Bıyıklı, 2013). Örneğin Türkiye'nin ilk kuşak entelektüellerinden Kazım Nami tarafından kaleme alınan 1934 tarihli Muallimin Meslek Ahlakı isimli kitapta öğretmenlerin kendilerini geliştirmeleri için yurt içinde, hususen Ankara'da birçok yeri gezmeleri, görmeleri gerektiğinin altı çizilirken Hacı Bayram Veli'den, Ankara Kalesi içinde bulunan Selçuklu ve Osmanlı eserlerinden, Akif'in evinden, Camilerden hiç bahsedilmediği görülür (Gündüz, 2015; Subaşı, 2003). Her iki örnek Cumhuriyet'le birlikte daha çok 
tercih edilmeye başlanan, tek parti dönemiyle iyice belirginleşen Osmanlı ve İslam kimliğine negatif yaklaşım ile bunun yerine ikame edilen seküler modernleşme projesini anımsatıcıdır. Dahası bu örtüşme anılan yaklaşım ile oluşturulan yeni tarih tezi ve bu tezin vatandaşlık eğitimi anlayışı üzerinden yapılandırıma biçimini, bu yapılandırmanın etkisi ve sürekliliğini göstermesi bakımından da ayrıca anlamlıdır (Akman, 2011). Oysa din ve dini değerlerden arındırılmış ya da bu tür değerlerle irtibatı yeterince düşünülemeden yapılan kültürel miras anlatımının birçok bakımdan geçmişi ve bu günü doğru anlamayı sınırlandıracağı söylenebilir. Kültürel mirasın öğretiminde gerek geçmiş gerekse günümüzü bir bütün olarak yansıtan, toplumsal ve kültürel gerçeklikle örtüşen bir tablo ortaya koymanın çocukların değer yönelimleri ile buna dayalı sağlıklı bir kimlik geliştirebilmeleri açısından daha anlamlı olacaktır.

İncelenen eserlerde belli kentler ve onların temsil ettiği değerler arasında kurulan irtibatlar, Türk Milli Eğitim felsefesi ve onun kurucu değerleri ile çeşitli biçimlerde ilişkilendirilebilse bile bu yaklaşım, Türk-İslam kültür ve medeniyeti ile bu medeniyet birikiminden bu güne gelen tarihsel mirasın objektif ve bütüncül sunumu bağlamında kimi yanlış anla(şı)malara kapı aralayabilir (Korlaelçi, 1999). Kültürel mirasın bütün birikim ve yönleriyle "biz" ile organik ilişkisini yeterince kurmadan yapılan sunumlar çocuğun geçmişle yeterince ve sağlıklı ilişki kuramamasını, buradan hareketle tarihsel derinliği olan bir kimlik oluşturamamasını tetikleyebilir. Bu durum ilk çocukluk dönemine yönelik değerler eğitimi noktasında önemli bir problem olarak karşımıza çıkmaktadır.

\section{Kaynakça}

Akman, Ş. T. (2011). "Türk Tarih Tezi Bağlamında Erken Cumhuriyet Dönemi Resmî Tarih Yazımının İdeolojik ve Politik Karakteri”, Hacettepe Hukuk Fakültesi Dergisi, 1 (1), ss. 80-109.

Altıntaş, M. E. (2016). Öğretmenler Gözüyle Değerler Eğitimi, Mostar Basım Yayın, Konya.

Bıyıklı, Ş. (2013). "Edebiyat Eğitimi ve İdeolojik Bağlanma”, Eğitime Bakış, Sayı: 26, Yıl: 9, ss. 75-80.

Cançelik, A. (2014). Şehirler ve Semboller, Şehir Üzerine Düşünceler - I, (edt. H. Taşçı ve Nebati, N.), Esenler Belediyesi Şehir Yayınları, İstanbul, ss. 28-43. 
Demirci, M. (2003). "İslam'da Şehir ve Şehrin Sosyal Dinamikleri", İstem, Sayı: 2, YIl:1, ss. 129-146.

Dönmez, C. \& Yeşilbursa, C. C. (2014). "Kültürel Miras Eğitiminin Öğrencilerin Somut Kültürel Mirasa Yönelik Tutumlarına Etkisi”, İlköğretim Online, 13 (2), ss. 425-442.

Gündüz, M. (2015). Erken Cumhuriyet Dönemi Eğitiminde Yeni Değerler ve İdeal Tipler, Değerler ve Eğitimi - II (edt. Recep Kaymakcan vdğ.), Dem Yayınları, İstanbul, ss. 805-828.

Karasar, N. (2000). Bilimsel araştırma Yöntemi, Nobel Akademik Yayıncılık, Ankara.

Kardaş, M. N. ve Cemal, S. (2017). "Değerler Eğitimi ve Türkçe Öğretiminde Değer Eğitimi Üzerine Yapılan Araştırmalara Iliş̧in Kaynakça Denemesi", Karadeniz Sosyal Bilimler Dergisi, 9 (16), ss. 383-412.

Kaya, Ö. (2012). "İstanbul: Bir İslam kenti”, Diyanet Aylık Dergi, Sayı: 264, ss. 14-17.

Kaymakcan R. ve Meydan, H. (2015). Öğretmenlere Göre Değerler Eğitimi Uygulamalarının Değerlendirilmesi: İstanbul Örneği, Değerler ve Eğitimi II, (edt. Recep Kaymakcan vdğ.), Dem Yayınları, İstanbul, ss. 277-306.

Kaynak, İ. H. ve Karabulut, T. (2016). "İnanç Turizmi Bağlamında Kentsel Turizm ve Kültürel Turizm: Konya Örneği", Selçuk Üniversitesi Sosyal Bilimler Enstitüsü Dergisi, Sayı: 35, ss. 185-191.

Korlaelçi, M. (1999). "Milli Kültürde Dinin Rolü”, Ankara Üniversitesi Illahiyat Fakültesi Dergisi, Cilt: 39, Sayı: 2, ss. 217-225.

Külcü, Ö. T. (2015). "Kültürel Miras Kavramının Eğitim Açısından Önemi”, Akademia Disiplinlerarası Bilimsel Araştırmalar Dergisi, 1 (1), ss. 27-32.

MEB (2016). Illköğretim Türkçe Dersi Öğretim Programı ve Kılavuzu (6, 7, 8. sınıflar), Milli Eğitim Bakanlı̆̆ı, Ankara.

MEB (2018). Türkçe Dersi Öğretim Programı (Illkokul ve Ortaokul 1, 2, 3, 4, 5, 6,7 ve 8 . Sınıflar), Milli Eğitim Bakanlı̆̆ı, Ankara. 
Özdemir, B. (2015). "Karakter Eğitimine Yönelik Yayınlanan Kitapların Nitelikleri”, Değerler ve Eğitimi - II, (edt. Recep Kaymakcan vdğ.), Dem Yayınları, İstanbul, ss. 693-706.

Selçuk, M. (1999). "Teorik ve Pratik Açmazlarılla Kültürel Miras Öğretimini Sorgulayan Bir Deneme", Ankara Üniversitesi Illahiyat Fakültesi Dergisi, Cilt: 39, Sayı: 2, ss. 255-264.

Sever, S. (2007), Çocuk Edebiyatı, Kök Yayıncılık, Ankara.

Subaşı, N. (2003). "Kültürel Mirasın Çeşitliliği ve Seçicilik Sorunu", Doğu Batı, Sayı: 25, Yıl: 7, ss. 135-147.

Yavuzer, H. (2001). Çocuk Psikolojisi, Remzi Kitabevi, İstanbul.

Yıldııım A. ve Şimşek, H. (2005). Sosyal Bilimlerde Nitel Araştırma Yöntemleri, Seçkin Yayıncılık, Ankara. 
Values Education In First Reading Books: An Analysis In The Cultural Heritage Discourse

Citation / ()- Osmanoğlu, C. (2018). Values Education in First Reading Books: An Analysis in the Cultural Heritage Discourse, Cukurova University Journal of Faculty of Divinity 18 (2), 1070-1101.

Abstract- In recent years, values education attracts considerable attention in our country. Especially, in the formal education system values education attracts more interest. Therefore, teaching of many values is observed to have been mentioned differently in teaching programs.

It is known that Turkish teaching programs, textbooks and literary works acquired for this purpose are important from the point of values education. In particular, children who start elementary school not only develop their capacity to comprehend literary works with literary works they read, but also they shape their value orientations. In this respect, it is necessary that the texts used in the first reading process should be sufficient in terms of value transmission as well as the narration features.

In this study, the values in the works trying to improve the reading and comprehension competencies of the students for the first grade primary schools were examined. Hence, three travel books (Mehmet'in Gezi Anıları; in Ankara, Istanbul, and Dardanelles) were selected and examined with qualitative data analysis themes around cover areas, highlighted spaces, written and visual descriptions of spaces, and examples of activity.

As a result of the study, it was seen that the elements used in visualization of the values such as city, identity and cultural heritage were effective in the works. However, various problems in the written depiction of these themes are underlined and discussed regarding the relation of these problems in the frame of childhood, cultural heritage and values education. Considering the developmental stage of children in terms of primary school, it has been mentioned that the problems in the presentation of historical and cultural heritage can lead to various problems in the value orientation of children and personality formation.

Keywords- First reading book, value education, cultural heritage. 